IZA DP No. 10033

Worker-Level Consequences of Import Shocks

Katariina Nilsson Hakkala

Kristiina Huttunen

July 2016 


\title{
Worker-Level Consequences of Import Shocks
}

\author{
Katariina Nilsson Hakkala \\ Aalto University \\ and VATT Institute for Economic Research \\ Kristiina Huttunen \\ Aalto University \\ and IZA
}

Discussion Paper No. 10033

July 2016

IZA

P.O. Box 7240

53072 Bonn

Germany

Phone: +49-228-3894-0

Fax: +49-228-3894-180

E-mail: iza@iza.org

Any opinions expressed here are those of the author(s) and not those of IZA. Research published in this series may include views on policy, but the institute itself takes no institutional policy positions. The IZA research network is committed to the IZA Guiding Principles of Research Integrity.

The Institute for the Study of Labor (IZA) in Bonn is a local and virtual international research center and a place of communication between science, politics and business. IZA is an independent nonprofit organization supported by Deutsche Post Foundation. The center is associated with the University of Bonn and offers a stimulating research environment through its international network, workshops and conferences, data service, project support, research visits and doctoral program. IZA engages in (i) original and internationally competitive research in all fields of labor economics, (ii) development of policy concepts, and (iii) dissemination of research results and concepts to the interested public.

IZA Discussion Papers often represent preliminary work and are circulated to encourage discussion. Citation of such a paper should account for its provisional character. A revised version may be available directly from the author. 
IZA Discussion Paper No. 10033

July 2016

\section{ABSTRACT}

\section{Worker-Level Consequences of Import Shocks*}

We analyse the effects of imports on employment and earnings by distinguishing between import competition in final products and firms' use of imports in production (offshoring). We use Finnish worker-firm data merged with product-level trade data. We focus on Chinese imports and instrument them by changes in China's share of world exports to other EU countries. Both types of importing increase the job loss risk for all workers and, in particular, for workers in production occupations. An increase in import competition has larger negative effects than an increase in offshoring. Production workers suffer the largest earnings losses, while for high- skilled workers the wage-effect is positive.

JEL Classification: F16, J23, J31, J63, L23

Keywords: offshoring, import competition, employment, earnings

Corresponding author:

Kristiina Huttunen

Aalto University

P.O. Box 21240

00076 Aalto

Finland

E-mail: kristiina.huttunen@aalto.fi

\footnotetext{
${ }^{*}$ Financial support from the Academy of Finland (Grant nr-134057) and the Yrjö Jahnsson Foundation is gratefully acknowledged. We are grateful to David Autor, Jakob Munch and participants at the Task workshop at Nuremberg 2014, ESSLE 2014 in Munich, and at seminars at University of Copenhagen, Copenhagen Business School and Norwegian School of Economics for helpful comments and suggestions. We thank Matti Mitrunen for excellent research assistance.
} 


\section{Introduction}

There has been a profound change in world trade in the last two decades. Falling transport costs, improvements in information and communication technologies, liberalized FDI regimes, and foremost the integration of China in the global economy have increased both import competition and offshoring of production in developed countries. The labor market consequences of these two phenomena may be very different. While import competition is expected to crowd out domestic production, the effect of imported intermediates on domestic production is ambiguous. On one hand, an increased use of imported intermediates substituting for domestic production may cause displacements and lower wages in domestic firms (Feenstra and Hanson 1996, 1999). On the other hand, the use of imported intermediates may improve firm productivity and competitiveness allowing the offshoring firm to expand and pay higher wages (Grossman and Rossi-Hansberg 2006, 2008). Most previous studies have focused on the effects of either import competition or offshoring on the labor market neglecting the possibly differential impact of the other channel. ${ }^{1}$

In this paper, we examine the impact of increased import penetration from China on employment and earnings of individuals over a short to medium run in a small open economy, namely Finland. We extend the current literature on labor market impacts of importing by distinguishing between the effects of an import shock on final product demand (import competition) and an import shock on the firm's own use of intermediates (offshoring intermediate inputs), and by focusing on individual-level employment outcomes. We argue that import shocks are expected to have a more instant impact on employment than on wages in countries where labour markets are characterized by a relatively weak employment protection and centralized and slow wage adjustments. ${ }^{2}$ Moreover, we dis-

\footnotetext{
${ }^{1}$ E.g. Acemoglu, Autor, Dorn, Hanson and Price (2016), Autor, Dorn and Hanson (2013, 2015), Autor, Dorn, Hanson and Song (2014), Balsvik, Jensen and Salvanes (2015), Dauth, Findelsen and Suedekum (2015), Ebenstein et al. (2014) analyze the effects of import competition measured as import penetration at industry level. Ashournia, Munch and Nguyen (2014) use firm-product-specific imports to analyze the wage effecsts of import competition. Hummels, Jørgensen, Munch, and Xiang (2014) use information on firm-specific imports to study the effects of firm-level offshoring. Kovak, Oldenski and Sly (2015) and Becker, Ekhom and Muendler (2013) define offshoring using information of affiliate employment changes.

${ }^{2}$ Balsvik, Jensen and Salvanes (2015) make the same point in their paper where they find clear employment but no wage effects of import competition from China to regional labor markets in Norway. They explain the lack of wage effects by Nordic welfare state and centralized wage bargaining.
} 
tinguish the impact of trade shocks by the workers' educational skills and occupation to understand which worker groups are affected the most.

We focus on Chinese imports for two reasons. First, Chinese imports to Finland consist both of final products and intermediate inputs, which allows us to analyse the shocks to both type of imports. Second, we follow an instrumental variable approach similar to one used in a few recent studies and we exploit the fact that the rapid increase in China's share of world manufacturing exports in the 2000s arguably appears to be driven by two exogenous factors; ${ }^{3}$ by changes in domestic policies impacting China's transition to a more market-oriented economy ${ }^{4}$ and changes in trade policies. We construct an instrument for the Chinese imports to Finland based on imports from China to other EU countries. ${ }^{5}$ For the increase in imports from China to other EU countries to be a valid instrument for firms' importing decisions in Finland, it is required that the growth is driven by supplyside factors in China and not by factors related to the demand for the products. Instead of using absolute values of Chinese imports to other EU countries, we construct a measure which relates Chinese imports to other EU countries to the world imports to other EU countries at the product-level. With the relative measure, we aim at isolating the Chinaspecific variation in the EU import growth from the variation due to demand shocks.

We use linked worker-firm data which includes all firms and the total of the working age population from Finland for 1998-2009. We match detailed firm-level data on imports and used intermediate goods to this data. The data allows us to identify the imports used by a firm in its production and imports that compete with the firm's final output and construct separate firm-specific measures for offshoring and import competition. We can also construct instrumental variables for Chinese import competition and offshoring that more precisely capture the exogenous shocks that individual firms are exposed to. Finally, the data allows us to follow individuals as they move to new employers or out of labour markets to observe their earnings and how individual-level characteristics such as

\footnotetext{
${ }^{3}$ China's share of world manufacturing exports have grown from $5 \%$ in 2000 to $16 \%$ in 2014 , at the same time as the developed countries have experienced large losses of jobs in manufacturing industries. World Development Indicators (http://data.worldbank.org/).

${ }^{4}$ See e.g. Naughton (2007); Hsieh and Klenow (2009); Hsieh and Ossa (2011), Bloom, Draca and Van Reenen (2016), Brandt, Van Biesebroeck, and Zhang (2012).

${ }^{5}$ Our identification strategy is related to methods used in Autor et al (2014) and Bloom et al (2016).
} 
education and occupation interact with the effect of importing on the worker-level labour market outcomes.

Our findings suggest that both offshoring and import competition increase the likelihood of job loss and non-employment, and import competition seems to have larger negative effects than offshoring. ${ }^{6}$ Doubling the mean level of offshoring to China increases the risk of separation from initial firm within two years by 4.8 percent, while the same relative increase in import competition from China increases the risk of separation by 13.5 percent. The effects on probability of employment are smaller, but larger for mediumskilled than for low- and high-skilled workers. While firm-level offshoring increases the risk of separation for high-skilled workers, it has a considerable smaller negative effect on the probability of being employed. This suggests that the high-skilled workers are more likely to move to a new employment after leaving their initial employer. When distinguishing workers by occupation, we find that workers in production occupations suffer from the largest negative effects on employment outcomes due to increased offshoring and import competition. The earnings effects are more heterogeneous; firm-level offshoring and import competition have a similar negative impact on the annual earnings of production workers as on their employment outcomes, but for the high-skilled the effects on earnings are positive and the opposite to the employment effects.

By focusing on the employment effects of importing for individuals, this study contributes to the previous literature where the majority of studies analyses the effects of trade shocks on earnings and wage premiums for different tasks and skills (e.g. Firpo et al., 2011, Baumgarten et al., 2013, Hummels et al., 2014, Ebenstein et al., 2014) or on employment at a more aggregated level. Only a few previous studies have examined the effect of imports on worker outcomes using individual level data. Autor et al. (2014) find that individuals who in 1991 worked in manufacturing industries that experienced a high subsequent import growth from China garner lower cumulative earnings, face an elevated risk of obtaining public disability benefits, and spend less time working for their initial employers and in their initial sector. Hummels et al. (2014) estimate the wage effects of

\footnotetext{
${ }^{6}$ This argument is based on comparing how much a $100 \%$ increase in the sample mean value of the measure affects outcomes.
} 
firm-level offshoring using Danish data on workers in firms which both import and export. In this way, they focus on the effects of within-firm changes in the intensity of trade. They find that within job spells, offshoring tends to increase the high-skilled wage and decrease the low-skilled wage, but the net trade effect of offshoring and exporting varies substantially within the same skill type and, conditional on skill, the wage effect of offshoring varies across occupational characteristics.

In our analysis, we choose an approach which avoids restricting the sample of workers by employment or firm status. We include both stayers and leavers and firms which do not import initially or later in the period of the study to assess the overall impact of offshoring and import competition on individual-level employment and earnings outcomes. In the more recent international trade literature focusing on offshoring, a distinction between skills and tasks is highly relevant since it has been argued that other characteristics than skill intensity determine whether job tasks are offshorable (Blinder, 2006). ${ }^{7}$ In particular, routine tasks and tasks that do not require personal interaction are more easily offshored (Levy and Murmane, 2004, Leamer and Storper, 2001, Blinder, 2006). The more recent studies, (e.g. Becker et al. 2013, Ebenstein et al. 2014 and Hummels et al. 2014), find that skills and occupation are important characteristics in distinguishing the impact of trade exposure on earnings. In addition, Bloom, Draca and Van Reenen (2016) show that an increased import competition from China causes an increased technological change within firms and reallocates employment towards more technologically advanced firms, thus leading to a fall in employment for low-skilled workers. To the best of our knowledge, Mion and Zhu (2013) is the only empirical study which uses both the industry-level measure for import competition and the firm-level measure for offshoring distinguishing between offshoring of finished and intermediate goods. They focus on the effects of importing on firm-level outcomes and find that the industry-level import competition from China reduces firm employment growth and induces skill upgrading in low-tech firms, while offshoring of finished goods to China actually increases firms' probability of

\footnotetext{
${ }^{7}$ The international trade literature on offshoring initially focused on whether low or highly skilled labour is more offshorable (e.g Feenstra and Hanson, 1996, 1999; Ekholm and Hakkala, 2006; Falk and Koebel, 2002; Hijzen et al., 2005; Strauss-Kahn, 2004).
} 
survival.

Our paper is also related to the literature which analyses the impact of permanent job loss on individuals. ${ }^{8}$ Only a few papers have examined the relationship between trade and job losses. Kletzer (2001, 2002) finds no association between imported intermediate goods and displacement rates in US industries, while Munch (2010) finds that firm-level outsourcing is associated with a higher unemployment risk for low-skilled workers. We apply the set up from the job displacement literature (e.g. Davis and von Wachter 2011) to analyse the effects of imports on employment at the individual level, and how workers adjust to these changes. Following individuals over some years after a trade shock is highly important since some time may be required before the potential worker-level consequences from increased trade emerge. Moreover, by instrumenting the import variables, our paper is the first that asks the question of how much do firm-level changes in offshoring or import competition increase the risk of job loss, and how do the effects vary by workers' characteristics.

We begin by providing a theoretical motivation in Section II and analyzing the trends in trade exposure and labor markets in Finland from the end of 1990's onwards in Section III. Section IV presents the data and the empirical framework. Section V presents the results. Section VI concludes.

\section{Theoretical Motivation}

As a theoretical motivation, we begin from a framework for a two-sector economy by Autor et al. (2014). In this setting, one of the domestic sectors is directly exposed to trade shocks in the rest of the world and the other is not. Trade shocks are supposed to be caused by productivity growth abroad, increasing the supply of products that compete with domestic production. In this setting, the trade shock will manifest itself as a fall in product demand in the economy's trade exposed industry, thus causing a reduction in the industry's demand for labour and an adjustment which goes through changes in nominal

\footnotetext{
${ }^{8}$ See e.g. Jacobson et al. (1993) and Couch et al. (2010). For Nordic evidence, see Eliason and Storrie (2006) for Sweden, Huttunen, Moen and Salvanes (2011) for Norway, and Huttunen and Kellokumpu (2016) for Finland.
} 
wages. Labour is perfectly mobile between sectors, equalizing the wages for similarly skilled workers in the long run, but not necessarily in the short run. ${ }^{9}$

In this paper, we assume similar trade shocks as those in Autor et al. (2013) arising from falling trade costs and productivity growth abroad, thus increasing the supply of foreign produced goods. We assume that trade shocks have an impact on firms and labour demand in the exposed industry through three channels. First, the increasing supply of competing imports will cause a fall in product demand in the economy's trade exposed industry and a reduction in the industry's demand for labour (the demand effect). ${ }^{10}$ Second, the increasing supply of foreign produced goods will induce firms to substitute domestically produced intermediates with imported intermediates. This second channel of trade shocks has an impact on the firms' and the industry's demand for labour in two different ways: 1) the demand for labour may fall if imported intermediates replace domestic labour either in the offshoring firm or in the domestic downstream producers of intermediates (the substitution effect) and 2) the demand for labour may increase if the use of cheaper imported intermediates increases the productivity in the offshoring firms (the productivity effect). ${ }^{11}$

In the short-run, the labour market outcome depends on how the negative demand and substitution effects counterbalance the positive productivity effect. In the transition to a new long-run equilibrium, all three effects may be active. The demand and substitution effects release labour in the exposed industry which, in setting of Autor et al., would reduce the nominal wages until enough workers move to the nonexposed sector. They state that if there are frictions in moving labor between industries, adjustment will be slow, forcing nominal wages in the exposed industry to remain below those in the nonexposed industry during the transition. We recognize that the demand and substitution effects put pressure on the nominal wages in the exposed industry, but if wages will not readily adjust downwards, the adjustment could force some workers into unemployment. When

\footnotetext{
${ }^{9}$ Non-labor factors of production are implicitly assumed to be immobile between sectors, as is the case in the specific factors model (Feenstra, 2004).

${ }^{10}$ This effect is the same as in Autor et al. (2013) paper.

${ }^{11}$ The labour supply effect and the productivity effect are modelled in the general equilibrium framework by Grossman and Rossi-Hansberg (2008).
} 
wages eventually adjust, workers will find new employment either in the exposed industry or in the nonexposed industry. The negative effects may be mitigated or counterbalanced by the positive productivity effect of offshoring, which allows firms to expand and employ more workers.

The resulting negative effects on employment are expected to be attributable entirely to the transitional phase, but they are increasing in the extent of wage stickiness and labor immobility across sectors in both the short and medium run. We suppose that there is an adjustment process with sticky wages, forcing some displaced workers into unemployment until the adjustment to a new long-run equilibrium has been reached. These assumptions fit the Finnish labour market better since its wage determination is relatively centralized and thus, neither firm-specific nor industry-specific shocks have an immediate impact on wages in Finland.

In Finland, the unions negotiate wage contracts with employer organizations separately in each industry, but these negotiations are typically co-ordinated by central organizations, thus leading to rather similar pay rises in different industries. As in the other Nordic countries, union density is very high in Finland $(71 \% \text { in } 2005)^{12}$ and the union wage contracts are also extended to non-unionized workers. Therefore, union contracts cover more than $90 \%$ of the workers, which is high but comparable to other Nordic countries and countries such as France, Italy and Spain (Venn, 2009). The employment protection legislation may also affect the employment adjustment of workers through dismissal costs. However, the Finnish labour law is not particularly strict. According to the OECD index of the stringency of the employment protection legislation from 2008, Finland is close to the OECD average (2.3 versus 2.2 on a scale from 0 to 6 , with 6 indicating the most stringent legislation). In sum, the Finnish labour market is characterized by a centralized wage setting and relatively weak employment protection. These features of the Finnish labour market motivate us to focus on the employment outcomes of trade shocks. We also estimate the effects on annual earnings and hourly wages in order to relate our analysis to the recent literature on the effects of imports on individual-level labour market outcomes. Before presenting the econometric model, we analyze the changes in the import exposure

\footnotetext{
$1270.7 \%$ in Denmark, $76.5 \%$ in Sweden and 54.5\% in Norway in 2005 (OECD Stat).
} 
and manufacturing employment from the end of 1990s onwards.

\section{Trade Exposure in Finland}

In Figure 1, we plot imports from China and the manufacturing employment share in Finland and the U.S. over the 1990-2009 period. We note that Chinese import penetration increased dramatically in the U.S. after China joined WTO in 2001 and until the financial crisis. The Chinese import penetration in Finland starts increasing in 2002, one year after China's accession to the WTO, but does not make a strong growth spurt until 2004 onwards. This suggests that the Chinese import shock hits Finland later than the U.S.. The period of strong import growth from China coincides with decreasing manufacturing employment as the share of total employment in both countries. ${ }^{13}$ Although the trend in manufacturing employment share is similar in the two countries, the level of the manufacturing employment share is about 10 percentage points higher in Finland, thus suggesting that Finland is still more dependent on manufacturing than the U.S..

Figure 1 here

It is possible that the increasing Chinese import penetration coincides with other significant changes in imports from low and middle income countries to Finland. We note two important facts in Figure 2, which plots the shares of imports to Finland from the most important low and lower middle income source countries. ${ }^{14}$ First, Chinese imports do not seem to have crowded out imports from other important low or middle income source countries. We only observe a smaller negative change in the Estonian import share after 2005. Second, Russia is the most important source country and, in addition to China, a

\footnotetext{
${ }^{13}$ Due to a deep recession, caused by a banking crisis and a collapse of export to the former Soviet Union, the total employment first decreased by $16 \%$ between 1990 and 1996 and then increased by $24 \%$ between 1996 and 2008 in Finland (computed from STAN Database, OECD). The large drop in the total employment explains why manufacturing employment as a share of the total employment stayed at a more stable level in the early 1990s. (See more about the economic crisis in Gorodnichenko, Mendoza, and Tesar 2012).

${ }^{14}$ We define the group of low and lower middle income countries by the definitions of the World Bank for 2001 .
} 
large contributor to import growth in the 2000s. Until its collapse in 1991, the former Soviet Union was an important Finnish trading partner. A decade after the collapse of Soviet trade, imports from Russia started to grow again; the growth is particularly strong from the mid 2000s until the financial crisis in 2008.

Figure 2 here

In Figure 3, we plot the composition and the changes of imports between 2001-2007 from the two most important low and lower middle income source countries, China and Russia. The figure confirms that the industries with large increases in imports are distinctly different between China and Russia. Imports from Russia have grown in raw materials and basic manufactures; Petroleum, Basic metals and Basic chemicals; while imports from China have grown in manufactured goods, particularly in TV, Radio and Telecom Equipment but also in Machinery and Equipment, Computers, Electrical Machinery and Equipment and Textiles, Clothing and Leather. Moreover, the plot reveals that the structure of the Chinese and Russian imports differs considerably. The most important import goods from Russia are either raw materials or basic manufactured goods, in particular Petroleum, Metal and Metal products, Chemicals and Wood, while the most important import goods from China are manufactured goods, in particular Machinery and Equipment, Computers, Electrical Machinery and Equipment, TV, Radio and Telecom Equipment and Textiles, Clothing and Leather. ${ }^{15}$ Thus, this figure suggests that Chinese imports consist of processed intermediate goods or final goods to a larger extent than Russian imports.

Figure 3 here

The stylized facts suggest that Finland has experienced a substantial change in the magnitude of Chinese import penetration in the 2000s. There has also been a strong increase in imports from Russia, but the observed differences in the composition of Chi-

\footnotetext{
${ }^{15} \mathrm{~A}$ further investigation of the Russian imports from the industry groups Metal and Metal products and Chemicals reveals that there are two industries that account for the largest share of imports in these groups, namely Basic Metals and Basic Chemicals.
} 
nese and Russian imports give us reason to expect that the changes in Chinese imports constitute a significant trade shock to the Finnish manufacturing sector, while Russian imports do not. In the econometric analysis, we will focus on the effects of Chinese import penetration on manufacturing employment and wages in Finland. In the introduction, we argued that the rapid Chinese export growth on the world market in the 2000s may be regarded as an exogenous trade shock which appears to be driven by two internal factors; changes in trade policies and in domestic policies which have an impact on production conditions.

\section{Data and Estimation Strategy}

This section introduces our main sources of data, our trade measures and the estimation strategy.

\subsection{Data Sources}

We use a register-based Finnish Longitudinal Employer Employee Database (FLEED) and Structure of Earnings data for the period 1999-2009, both from Statistics Finland. To construct measures of offshoring and import competition and their instrumental variables, we use firm-level trade data from Finnish Customs, combined with firm-level intermediate product data from Statistics Finland and data for commodity imports from the UN COMTRADE database. The data sets are linked together with unique firm identification numbers. The FLEED includes all individuals and contains detailed information on individual characteristics including education, occupation, annual wages, gender, family status and previous work history. This data allows us to follow individuals over time and to derive outcome variables of employment status and annual earnings. The Structure of Earnings data provides us more detailed information about earnings, in particular, hourly wages, but does not include all workers. ${ }^{16}$ In the econometric analysis, we use both an-

\footnotetext{
${ }^{16}$ Workers in firms with less than five employees and workers in the private sector with an employment spell starting or ending in the middle of a data collection month, and workers with no employment are excluded.
} 
nual earnings and hourly wages as earnings outcome variables. The firm-level information comes from financial statement panel. The panel includes variables such as value added, capital stock (book value), number of employees, wages, sales, and industry.

The firm-level trade data, which we use to construct measures of offshoring and import competition, is available at the level of the 8-digit Combined Nomenclature (CN8) by country of origin from 1999 onwards. ${ }^{17}$ Stemming from compulsory registration in Finnish Customs, data on imports from outside the EU consists of all trade transactions. Data for trade transactions to other EU countries is available for all firms with an annual import to all other EU countries above 100000 euro. ${ }^{18}$ According to information from Finnish Customs, the data incorporates about 96.5 percent of the total imports from other EU countries. To construct instruments for our offshoring and import competition variables, we collect trade data for EU countries at the level of the 6-digit Harmonized System product categories (HS6) for commodity imports from the UN COMTRADE database. For the offshoring instrument, we also use the firm-level information for intermediate products (imported and domestic) that we obtain from Statistics Finland's Industrial Ouput data for manufacturing firms. We aggregate the firm-specific information of used intermediate products to 4-digit level of industries (NACE rev 1.1.) for our purposes. ${ }^{19}$

We restrict our analysis to manufacturing firms which have a minimum of 20 employees at least one year during the studied period and to the individuals aged 20-55 years employed at these firms in a base year. We define 2000-2006 as base years, and follow individuals three years after the base year in the econometric analysis. The trade information is from year $t$ (2001-2007). To avoid the results to be driven by the Financial Crisis starting in 2008, we choose 2006 as the last base year included into the analysis.

The occupational codes in our data are from two different sources. The FLEED statistics has three-digit ISCO-88 occupational code information for all employed individuals

\footnotetext{
${ }^{17}$ The Combined Nomenclature, used by EU countries, is an extended version based on Harmonized Commodity Description and Coding System (Harmonized System, or HS).

${ }^{18} \mathrm{EU}$ countries may set this threshold themselves. 100000 euro is a threshold applied in several EU countries.

${ }^{19}$ We use data at the 4-digit level of industries rather than the more disaggregated 6-digit level of product classes (prodcom PC6) since the concordance between PC6 and HS6/CN6 (international trade data) has many one-to-many and many-to-many translations between the codes, see Van Beveren, Bernard and Vandenbussche (2012).
} 
in the years 2000, and 2004-2009. For the years missing occupational code in FLEED, we first complement the occupational codes from Structure of Earnings data which has three-digit ISCO codes for the entire time period, 1999-2009, but does not cover all individuals in the sample. For the individuals missing an occupational code both in FLEED and Structure of Earnings data (2001-2003), we enter an occupational code which is the nearest non-missing year observation.

In our econometric specifications, we distinguish workers by the level of education and occupation. We use three educational categories; low-skilled workers have lower secondary education (9 years of education), medium-skilled upper secondary education (12 years) and high skilled tertiary education (>12 years), and six occupational categories; clerks, service workers, operators and assemblers, trades and construction workers, professional workers and managerial workers (see Table B4 in Appendix B for the definitions). The occupational categories are chosen to distinguish different dimensions of task content of jobs that are relevant for analyzing the effects of increased importing. ${ }^{20}$ In particular, routine tasks and tasks that do not require personal interaction can more easily be offshored (see e.g. Levy and Murmane, 2004, Leamer and Storper, 2001 and Blinder, 2006). Offshoring of such tasks may actually reduce job opportunities in middle-skilled production occupations in manufacturing. Low-skilled workers, carrying out routine manual and cognitive tasks in service and clerical occupations such as cleaning, cashiers, sales staff and plumbers, on the other hand, are less likely to be replaced by machines and computers, and are also much less susceptible to offshoring if their job tasks have a geographical attachment to other operations and customers. Moreover, non-routine cognitive personal and analytical tasks, typically carried out by professionals and managers, are described as such that they cannot easily be codified and performed by computers. ${ }^{21}$ For the same reasons, they most likely require some geographical proximity to the other operations and cannot easily be offshored.

\footnotetext{
${ }^{20}$ We use occupational categories rather than measures of task content of occupations to maintain transparency in the analysis.

${ }^{21}$ For the purpose of studying how computers have affected relative demand for job tasks, Acemoglu and Autor (2011) define job tasks into the seven categories; non-routine cognitive personal, non-routine manual physical, non-routine cognitive analytical, non-routine manual personal, routine cognitive, routine manual and offshorable.
} 


\subsection{Defining and Measuring Trade Shocks}

As motivated in previous sections, the effects of import competition may differ from the effects of the firm's own imports of intermediate goods (offshoring). In the empirical analysis, we distinguish between the impacts of the firm's own offshoring and the impacts of import competition.

We define our offshoring measure as narrow offshoring including imported goods from the industry of the importing firm, i.e. a firm's purchases of imported goods produced in the same industry (at the two-digit level of NACE rev 1.1). ${ }^{22}$ Defining offshoring in terms of imported own-industry goods captures offshoring caused by outsource offshoring to external foreign suppliers and in-house offshoring to foreign affiliates to the extent that these phenomena involve imports back to the home country for further processing or resales. ${ }^{23}$ We relate firm $i$ 's own industry imports to total production to control for changes in imports due changes in the firm size and define firm-level offshoring shock as a change in the intensity of imported intermediates in total production:

$$
C O F F_{i j t}=\frac{\sum_{k \in j} m_{i j t}^{\text {China }}}{y_{i t}}
$$

where $\sum_{k \in j} m_{i j t}^{\text {China }}$ is the imported goods $k$ from industry $j$ from China and used by firm $i$ from industry $j$ (two-digit NACE rev 1.1) and $y_{i t}$ is firm $i^{\prime} s$ production.

In order to separate the firm's own use of imported goods (offshoring) from the total import of goods (import competition), we construct a firm-specific measure of import competition. We deduct firm $i$ 's own imports of goods from industry $j$ (at the three-digit level of NACE rev 1.1) $\sum_{k \in j} m_{i j t}^{C h i n a}$ from the total imports of goods from industry $j$ in China to Finland, $M_{j t}^{C h i n a}$ :

\footnotetext{
${ }^{22}$ Feenstra and Hanson (1999) distinguish between narrow and broad offshoring. Narrow offshoring only includes imported intermediate inputs from the importing industry, i.e. an industry's purchases of imported inputs produced in the same industry. Broad offshoring also includes imported non-energy inputs from all other industries. They prefer the narrow to the broad measure, since it is closer to the phenomenon of fragmentation and vertical specialization that takes place within industries.

${ }^{23}$ The measure does not capture offshoring of the final stages of production or other production that is not shipped back to the home country for further processing.
} 


$$
C I P_{i j t}=\frac{M_{j t}^{C h i n a}-\sum_{k \in j} m_{i j t}^{C h i n a}}{M_{j t}-\sum_{k \in j} m_{i j t}+Y_{j t}}
$$

where $M_{j t}$ are the total import of goods from industry $j$ to Finland, $\sum_{k \in j}^{C h i n a} m_{i j t}$ are the imported goods from industry $j$ used by firm $i$ from industry $j$ from China, $\sum_{k \in j} m_{i j t}$ are the all imported goods $k$ from industry $j$ used by firm $i$ in industry $j$, and $Y_{j t}$ is the total domestic sales by firms in industry $j$ in Finland. ${ }^{24}$

Before presenting our individual-level specification, we first analyse how changes in offshoring and import competition from China are related to different outcome variables at the firm-level. Since the shocks are defined at the firm-level, we want to describe how these shocks are correlated with employment, sales and exporting of the firms. The results for firm-level FE-estimations in Table A1 in Appendix A suggest that increased offshoring from China is associated with a decrease in firm-level sales, while increased import competition from China is associated with a decrease in firm-level employment and sales. Further, neither of the import measures is associated with changes in the export share or the educational skill shares.

\subsection{Individual-Level Specification}

To analyse the responses to Chinese import shocks at the worker level, we construct a sample of workers who were employed in a manufacturing firm at the end of a base year, $t-1$, (years 2000-2006). We follow the workers to years $t, t+1$ and $t+2$ regardless whether they remain in the labour force or not. We use three different outcome measures: 1) employed in same firm, which is an indicator that has the value of one if individual $h$ did not separate from firm $i$ between $t-1$ and $t(+k) ; 2)$ employment, which is an indicator of whether the individual is employed in year $t(+k)$, and; 3) annual earnings (including zeros) in year $t(+k)$, where $k=0,1$,or 2 . Table A2 in Appendix A reports the means of background and outcome variables for this sample.

\footnotetext{
${ }^{24}$ This firm-specific measure similar to the import competition measure is used by Ashournia et al. (2014) by excluding the imports that are used by the firm $i$ as intermediates and, by definition, do not compete with firm $i$ 's production.
} 
To analyse how firm-level offshoring or firm-specific import competition affects workerlevel outcomes in different $t(+k)$ during and following the import shock, we estimate the following specification:

$$
Y_{h t+k}=\mathbf{X}_{h t-1}^{\prime} \beta+\mathbf{Z}_{i t-1}^{\prime} \gamma+\delta_{1} C O F F_{i j t}+\left(\delta_{2} C I P_{i j t}\right)+\alpha_{h i}+\theta_{t}+\varepsilon_{h i t}
$$

where $Y_{h t}$ is an indicator variable for the worker-level outcome for individual $h$ in year $t+k . \mathbf{X}_{h t-1}$ is a vector of observable worker characteristics from the pre-shock period $t-1$. These include age, age squared, tenure dummies $(2,3,4-10,>10$ years), a dummy for having children aged below seven years, a dummy for having children aged below 18 years and interaction variables between respective two former variables and a female dummy. $\mathbf{Z}_{i t-1}$ is the vector of firm variables, which includes a log of number of employees in the main specification ${ }^{25}$ and $\alpha_{h i}$ is the individual-base-year-firm specific fixed effect (initial job spell fixed effect) and $\theta_{t}$ is the time-specific dummy variable. Our main variables of interest are firm-level Chinese offshoring, $C O F F_{i j t}$, and firm-specific Chinese import competition, $C I P_{i j t}$. We measure offshoring and import competition in year $t$ which is the year after the base year.

We estimate the model by OLS as a linear probability model with individual-base-yearfirm specific fixed effects separately for years $t, t+1$, and $t+2$. By including the individualbase-year-firm fixed effects, we can control for time invariant unobserved heterogeneity between firms and individuals. ${ }^{26}$ The model with firm-individual fixed effects captures how a change in imports within the base-year firm affects the probability of separation (the probability of employment, annual earnings) for the given individual. Note that the base-year firm for each individual is the firm where the individual was working at the end of the year $t-1$. We do not require individuals to remain employed in these firms in years $t, t+1$, and $t+2$, i.e. when the outcome is measured. This way, we can estimate the impact of the import shocks on employment outcomes, without restricting the analysis to a selective group of workers who keep their jobs. Our approach is related to that of

\footnotetext{
${ }^{25}$ We also estimate regressions including firm export share variable in period $t$ to control for changes in labour demand arising from export shocks. The results are not affected in any important way.

${ }^{26}$ In section 5.3 we report the results of model without fixed effects, and with base-year firm fixed effects.
} 
Autor et al. (2013) where workers are attached to pre-shock industries and Hummels et al. (2014) where workers are attached to pre-shock employers and it is also related to Walker (2013) and Menezes-Filho and Muendler (2011) using longitudinal data.

\subsection{Instruments}

An obvious concern with the importing measures is that the firms' importing decisions are jointly determined with their employment decisions. In order to investigate the causal effect of importing on earnings and the employment of workers, we employ an instrumental variable approach. The approach requires that the instrument is correlated with firms' importing decisions (changes in offshoring), but it should not be correlated with factors that influence their employment decisions, productivity or demand for final products in any other way.

We exploit the fact that the growth of Chinese export appears largely to be driven by changes in trade policies and domestic policies in China. ${ }^{27}$ In particular, industrial production increased rapidly as a result of improving productivity, increased capital accumulation, migration to urban areas, and enhancements in infrastructure. On January 1, 2001, China joined WTO which gave an additional boost to the Chinese manufacturing industries. The WTO membership implied that China committed to a step-wise relaxation over 7,000 tariffs, quotas and other trade barriers over a transition period of 2001-2007. Dismantling of import barriers gave the Chinese importers better access to foreign inputs. In 2005, an extensive import quota system called the Multifiber Arrangement, set by EU, US and Canada on Chinese imports in 1974, was phased out and there was also a change in exporting law in China, which made it easier to obtain an exporting license for certain products. Altogether, the changes in the trade regime benefited the production of goods that depended on imported intermediates and that were exported.

We base our identification strategy on the growth in Chinese imports to countries that were EU members before 2000, excluding Finland, at the three-digit level of manufacturing

\footnotetext{
${ }^{27}$ Autor et al (2014) use variation in Chinese export supply to high-income countries, Hummels et al (2014) variation in world export supply and Bloom et al (2016) use variation due to the removal of product-specific quotas following China's entry to the World Trade Organization in 2001.
} 
industries (three-digit NACE rev 1.1). ${ }^{28}$ For the increase in Chinese imports to be a valid instrument for firms' importing decisions in Finland, it is required that the growth is driven by supply side factors in China and not by factors related to demand of the products. A potential threat to our identification strategy is that product demand shocks are correlated across EU countries, implying that our instrumental variables (IV) estimates may be contaminated by the correlation between import growth and the unobserved components of product demand. This would tend to bias a negative impact of trade exposure on earnings and employment toward zero. To neutralize the potential demand-side factors, we construct measures which relate the Chinese imports of products $k$ from industry $j$ to EU countries to the aggregate world imports of products $k$ from industry $j$ to the EU countries in year $t$. In this way, we aim at excluding the effect of world demand shocks from the China-specific variation in export supply. ${ }^{29}$ While using import statistics, we name the instruments as China relative export supply, CRES.

To create an instrument for offshoring (importing of intermediate inputs), we weight the imports of product $k$ from China with the average share of the intermediate product (imported or domestic) in the total use of inputs by firms $i$ in industry $j$ in the presample years of $1998-1999 \bar{s}_{k j},{ }^{30}$

$$
C R E S_{-} I N P_{j t}=\sum_{k} \bar{s}_{k j} \frac{C E S_{k j t}^{E U}}{W E S_{k j t}^{E U}}
$$

where $C E S_{k j t}^{E U}$ is China's imports of products $k$ from industry $j$ (three-digit NACE rev 1.1) in year $t$ to EU countries and $W E S_{k j t}^{E U}$ is the sum of the world imports of products $k$ from industry $j$ to EU countries, both excluding the imports to Finland. ${ }^{31}$ The instrument will capture the variations in Chinese imports that are caused by exogenous factors (trade

\footnotetext{
${ }^{28}$ The countries are Austria, Belgium, Denmark, France, Germany, Greece, Ireland, Italy, Netherlands, Portugal, Spain, Sweden and UK.

${ }^{29}$ We will also check the robustness of the results when using an instrument that exploits the absolute variation in Chinese exports (as in Hummels et al. 2014) and using aggregate world export supply of products $k$ from industry $j$ as the nominator. It is important to note that part of the variation in the latter may also reflect negative or positive import shocks from other countries.

${ }^{30}$ We obtain the information for intermediate inputs from Industrial output data for manufacturing firms. Weights are computed as shares of products (defined at 4-digit level of industries) in total use of intermediates at the 3-digit level of industries (NACE rev 1.1).

${ }^{31}$ As a measure of export supply we use imports reported by EU countries.
} 
policies and China's domestic policies) affecting China's relative share the world exports of the product $k$ from industry $j$. However, for the exclusion restriction to hold, we also need to assume that the average presample input structure (the initial share of product $k$ in the input mix) in an industry is not correlated with employment changes through any other channel than through the changes in imports. We argue that industry average weights constitute a better guarantee for this than firm-specific weights.

For the import competition measure, we use China's unweighted relative export supply at the industry-level as the instrument

$$
C R E S_{-} I N D_{j t}=\frac{C E S_{k j t}^{E U}}{W E S_{k j t}^{E U}}
$$

where $C E S_{k j t}^{E U}$ and $W E S_{k j t}^{E U}$ are defined as above. Thus, we exploit the same source of variation in both instruments, but the difference is that the offshoring instrument is weighted by the initial input structure of the industry. For this reason, we estimate separately the impact of import competition and offshoring when using the IV strategy.

\section{The Effect of Offshoring and Import competition on Worker Outcomes}

\subsection{Employment Outcomes}

We begin by estimating equation (3) including all workers employed in the firms in the base year and using the two outcome variables: 1) employed in the same firm as in period $t-1$ and; 2 ) employment. ${ }^{32}$ The specification includes worker base-year firm fixed effects and the standard errors are clustered at the period $t-1$ firm level.

Table 1 reports the results for the fixed effect and fixed effect-IV estimations for the two import shocks, offshoring and import competition, the three time periods $t, t+1$ and $t+2$, and the two outcome variables. The period $t$ effect tells us whether an increase in the firm's offshoring while employed in the initial firm affects the likelihood that the

\footnotetext{
${ }^{32}$ Table A2 in Appendix A shows mean values for the different outcome variables.
} 
individual is still employed in the firm (or employed anywhere). By looking at the effects in the next two years $(t+1$ and $t+2)$, we want to examine whether changes in the level of offshoring (import competition) affect the separation probability immediately or with a time lag.

The fixed-effect estimates in columns 1 to 3 in Panels A and B of Table 1 indicate that both increased firm-level offshoring and import competition are associated with a reduced probability of an individual being employed in the same firm in period $t$. The negative effect of offshoring is not statistically significant until time period $t+2$. This indicates that offshoring has an effect after an adjustment period. In order to make the estimated effects of offshoring and import competition on employment outcomes comparable, we compute relative effects for an increase equal to the sample mean of the respective measure. An increase equal to the sample mean of offshoring to China (the mean 0.45 percent doubles to 0.90 percent) is associated with a -0.69 percent decrease in the probability of being employed in the same firm in year $t+2{ }^{33}$ The effect of import competition is largest in the first year. An increase equal to the sample mean level of import competition from China (the mean 1.25 doubles to 2.5) is associated with a 1.07 percent decrease in the probability of being employed in the same firm in year $t .^{34}$

In Panels D and E we report results using employment as an outcome variable. Both offshoring and import competition have a larger negative association with the probability of remaining employed in the initial firm than with the probability of being employed. This suggests that part of the workers leaving firms with increased imports immediately find new employment elsewhere. Panel $\mathrm{C}$ and $\mathrm{F}$ show the results from estimating a specification which includes both the offshoring and the import competition measure. The estimates largely remain the same when both measures are included.

\section{Table 1 here}

Next, we analyse the results for the fixed-effect-IV estimations. The first-stage es-

\footnotetext{
${ }^{33}$ The percentage effect is computed as $-0.011 * 0.45 / 0.7152 * 100=-0.692$. The means are reported in Table A2 in Appendix A.

${ }^{34}$ The percentage effect is computed as $-0.0079 * 1.25 / 0.9205^{*} 100=-1.073$.
} 
timates for the instrumental variables are reported in column 4 in Table 1 . As expected, the weighted and unweighted Chinese relative export supply, $C R E S_{-} I N P_{j t}$ and $C R E S_{-} I N D_{j t}$, increase offshoring at the firm level and import competition at the industry level, respectively. In columns 5 to 7 in Table 1, we report the second stage estimates for the two import variables. When instrumenting offshoring and import competition, we find the effect on the probability of being employed in the same firm to remain negative, but the effect is larger in magnitude than in the FE estimations. This reflects the positive selection bias in our FE estimations. Workers in importing firms have lower separation probabilities than workers in other firms. This is consistent with the idea that importing may be associated with other factors that have a positive influence on firm growth. The results indicate that an increase equal to the mean level of offshoring to China increases the probability of the worker leaving the initial employer by 4.8 percent, while an equally large increase in import competition increases the probability by 13.5 percent in $t+2$. Both offshoring and import competition have also a negative effect on the likelihood of remaining employed, but the effects are considerably smaller and less precise than the effects on separation probability. Doubling the mean level of offshoring to China decreases the likelihood of employment by 0.9 percent in period $t+2$ and the same relative increase in import competition increases the likelihood by 2.5 percent. These results suggest that, for an equally large relative change in the two measures of importing, Chinese import competition causes a more profound restructuring of employment within firms than firms' own offshoring to China.

To analyse whether offshored job tasks tend to be carried out by low-, medium- or high-skilled workers, we next estimate the effects of offshoring separately for workers with different educational skills. Table 2 reports the results on the effects of offshoring and import competition on employment for workers in the three educational groups. ${ }^{35}$ The FE-IV estimation results in columns 5 to 7 suggest that the effect of offshoring is negative and larger than in the fixed effect estimations (columns 1 to 3 ) in all skill groups. Consistent with the FE-results, offshoring has the largest negative effect on the probability of remaining employed in the same firm (Panel A) for the medium- and high-skilled groups.

\footnotetext{
${ }^{35}$ See Section 4.1. for the definitions.
} 
Doubling the mean offshoring to China increases the risk of separation from initial firm by 6.9 percent, and the risk of non-employment by 2.2 percent for medium skilled in $t+2$. The effects are smaller for the low-skilled workers (2.9 respective 1.3 percent in $t+2$ ). Offshoring also increases the separation risk for high-skilled workers $(4.3$ percent in $t+2)$, but has none or a considerably smaller negative impact on the probability of being employed. Thus, this suggests that the high-skilled workers are more likely to move to a new employment after leaving their initial employer. This could be explained by the fact that

high-skilled have a higher propensity to leave voluntarily and even when forced to leave, they may have better labour market outcomes than medium- and low-skilled workers.

Table 2 here

Import competition may also have a differential impact on workers in different skill groups: production that faces higher import competition may use workers with certain skills more intensively and the way firms respond to the shock may affect a certain type of workers more profoundly. The results from the FE estimations in Panels C and D in Table 2 indicate that increased import competition is associated with a higher risk of separation and non-employment, especially for medium- and high-skilled workers. The effect of overall Chinese import competition on the risk of job loss and non-employment is negative in most specifications and has the largest impact for medium-skilled workers. Doubling the mean level of import competition from China increases the risk of separation from the initial firm by 11.2 percent for medium-skilled, 4.3 percent for low-skilled and 0.8 for high-skilled workers within two years. However, the impact of import competition from China on the risk of non-employment is smaller for low-skilled (1.7 percent) than for medium- (3.7 percent) and high-skilled workers (2.7 percent) in period $t+2$.

Table 3 and Figure 4 here

Finally, we analyse how the effects vary by occupation. As we argued before, educational skills may be too crude a measure for defining the offshorability of jobs and their sensitivity to import competition. We use occupational categories as a proxy for the task 
content of the jobs. Figure 4 shows the FE-IV results in a dynamic view by plotting the effect of offshoring on the risk of job loss and nonemployment by occupational categories in year $t, t+1$ and $t+2$. The results are also reported in Table 3 together with the first-stage FE-IV and the FE estimation results. ${ }^{36}$ As seen in the upper panel of Figure 4, the results indicate that increases in offshoring increase the risk of job loss and non-employment for almost all worker types, especially for Operators and assemblers and Professional workers. Workers in Clerk, Service and Trades and construction occupations have also an increased probability of leaving the initial firm but the risk of non-employment is almost unaffected by offshoring. For Operators and assemblers, doubling offshoring increases the probability of job loss by 11.4 percent, and the probability of non-employment by 4.9 percent within two years. For Professional workers, the same change in offshoring increases the probability of job loss by 4.2 percent and the probability of non-employment by -0.4 percent within two years.

In lower panel of Figure 4, we report the FE-IV results of import competition on worker outcomes. Once more, the results indicate the largest risk of separation from the initial firm for Operators and assemblers and Professional workers. Doubling the mean level of import competition increases the probability of separation within two years by 11.0 percent and the probability of non-employment by 3.9 percent for Operators and assemblers. For Professional workers, we are not able to compare the effects of import competition and offshoring reported in Table 3 since the first stage is not significant for the instrumental variable of import competition. When using an alternative instrument, we find the comparable effects of import competition on the probabilities of separation and non-employment to be 13.9 percent and 2.2 in period $t+2$ for Professional workers. ${ }^{37}$ Thus, for Operators and assemblers, the effect of industry-level import competition is relatively

\footnotetext{
${ }^{36}$ The FE results indicate that growth in offshoring is associated with a higher risk of separation and nonemployment for Trades and construction workers, and for Professionals. The risk of nonemployment increases also for Operators and assemblers.

${ }^{37}$ The alternative instrument is defined as $\frac{C E S_{k j t}^{E U}}{W E S_{k j t}}$, where $C E S_{k j t}^{E U}$, is China's export supply of products $k$ from industry $j$ (three-digit NACE rev 1.1) in year $t$ to EU countries excluding the supply to Finland and $W E S_{k j t}$ is the sum of the world export supply of products $k$ from industry $j$. The first stage is significant and the second-stage estimates are -0.079 (0.040) for same firm employment and -0.016 (0.005) for employment in period $t+2$.
} 
similar to the effect of firm-level offshoring (when comparing a similar percentage increase in the mean), while for Professional workers import competition seem to lead to a higher risk of separation than offshoring.

We may conclude that the effects of offshoring and import competition on employment outcomes are heterogenous; the groups that suffer the most are the medium skilled, and workers in production occupations, such as Operators and assemblers and Trades and construction workers. Low-skilled workers in Clerk, Service and Trades and construction occupations, who carry out routine manual and cognitive job tasks to a larger extent, face also an increased risk of job loss but not of remaining non-employed. The results in Tables 1 to 3 and Figure 4 suggest that the two measures have a similar pattern of impacts on employment outcomes. However, the effect of import competition on the risk of job loss and non-employment is larger in magnitude than the effect of offshoring.

The question is whether the effects found are economically significant. A one-hundred percent increase in the mean values of offshoring and import competition (0.45 and 1.25, respectively) is relatively large. A comparison should be made of the fact that during the period studied from 2001 to 2007, the mean value of offshoring to China increased from 0.13 to 0.86 and the mean value of import competition from China increased from 0.87 to 1.70. However, there is a large variation in the measures suggesting that some firms and industries experienced quite large changes while other firms and industries remained unaffected. ${ }^{38}$

\subsection{Earnings Outcomes}

We argued earlier that trade shocks are more likely to have an impact on employment rather than earnings in the short run in a country like Finland where the labour markets are characterized by centralized and slow wage adjustments, but a relatively weak employment protection. A limitation of the employment variables is that they only measure outcome on the extensive margin, while adjustment to trade shocks could also take place on the intensive margin, both in the number of hours worked and wages. To address this issue,

\footnotetext{
${ }^{38}$ Standard deviation and max value equal to 1.689 and 252.33 for COFF, and 3.580 and 42.24 for CIP, see Table A2 in the Appendix.
} 
we also use earnings as an outcome variable.

We use two earnings measures from two different data sources; 1) annual earnings, which come from the same data as the employment measures (FLEED) and include all observations, even individuals with zero earnings; and 2) hourly wage which comes from Structure of Earnings data from Statistics Finland and has a large coverage of workers employed in private and public sectors, but does not include all workers. ${ }^{39}$ The annual earnings variable has the advantage that it captures employment changes on the intensive margin as changes in the hours worked, but it also has the disadvantage of mixing employment and wage changes. Hourly wage, on the other hand, is a precise measure of earnings for employed workers, but we can only observe this outcome conditional on employment.

Our strategy is to relate exogenous changes in offshoring and import competition to changes in labour incomes, after controlling for the worker-initial firm fixed effects and time varying characteristics of the worker. More specifically, we replace the outcome variable $Y_{i t+k}$ with a labour income measure in specification (3) in Section 4.3.. In the estimations using annual earnings, we include all workers who were initially employed in the firms, that is, even the displaced workers with no labour incomes and in estimations using hourly wage, we include workers employed in the initial firm or all workers who remain employed.

Table 4 reports the estimation results for the total sample of workers. ${ }^{40}$ The FEestimates in Panel A indicate a positive but very small and not statistically significant effect on the annual earnings of the employees in $t, t+1$ and $t+2{ }^{41}$ The FE-IV estimates for offshoring are not significant, indicating no earnings effect of offshoring on average. The FE-estimates in Panel B suggest that import competition is negatively but modestly associated with the annual earnings, while the FE-IV model indicates no effects. We are not surprised to find non-zero earnings effects of importing for the total sample of workers, considering that we found the effects on employment outcomes to vary by skills and occupations.

\footnotetext{
${ }^{39}$ Workers in firms with less than five employees and workers in the private sector with an employment spell starting or ending in the middle of a month, and workers with no employment are excluded.

${ }^{40}$ The first-stage estimates are reported in Table B1 in Appendix B and are statistically significant.

${ }^{41}$ Doubling the mean offshoring yields at most a $0.27 \%$ effect. The percentage effect is obtained by dividing the effect by mean earnings reported in Table A2 multiplied by $100(207.2764 * 0.45 / 35023 * 100=0.27)$.
} 
Table 4 here

To analyze the heterogeneity in the effects on earnings, we allow the coefficients for offshoring and import competition to differ for high-skilled workers and for workers in production occupations (including Operators and Assemblers and Trades and Construction workers). The estimates reported in Panel $\mathrm{C}$ in Table 4 suggest that the effect of offshoring on the annual earnings is positive for the employees with a tertiary education and negative for the other employees. Doubling the mean level of the offshoring measure (an increase from 0.45 to 0.9 ) increases the annual earnings of employees with a tertiary education by 1.1 percent in period $t+2$ (FE-IV estimates). The estimates in Panel $\mathrm{D}$ suggest that the effect of import competition is similar but the magnitude is considerably larger. Doubling the mean level of the import competition measure (an increase from 1.25 to 2.50) increases the annual earnings of employees with a tertiary education by 5.9 percent in period $t+2$.

In Panels $\mathrm{E}$ and $\mathrm{F}$ in Table 4, we report the results from estimations including interaction terms both for high-skilled workers and for workers in production occupations. As expected, the estimates suggest that the production workers who suffer the largest employment losses from increased offshoring and import competition, also suffer the largest earnings losses. A one-hundred percent increase in offshoring or import competition has an equally large effect, both reducing the annual earnings of workers in production occupations by 2.6 percent in period $t+2$.

Next, we estimate the effects on log hourly wages. We define two sub-samples of employees; 1) employees that remain employed in the initial firm and 2) the employees that remain employed in the initial or some other firm. It is important to keep in mind that both of these groups are selected: workers who remain employed despite the trade shocks are likely to differ from other workers hit by the shock also by unobservables. Those separating and finding employment in other firms may also be different. The separation could be voluntary, and even in the case that it is not voluntary, the workers who immediately find a new employment constitute a selective group as compared to the excluded group of workers with no labour incomes. 
Table 5 reports the results for the FE-IV estimations with log hourly wage as an outcome variable. ${ }^{42}{ }^{43}$ The results in Panel A show that the effect of offshoring on wages is positive for the workers with a tertiary education. Since the dependent variable is in log-form, the estimates in Table 5 express the effect for a one-percentage point increase in the offshoring or import competition measure. However, to make the results comparable with the results in Table 4, we compute the effects for the same magnitude of a change, that is, a-hundred percent increase in the mean value of the respective measure. Doubling the mean value of offshoring increases the wages of the employees with a tertiary education who remain in the initial firm by 0.59 percent in period $t+2$. Panel B shows that the impact of import competition is also positive for workers with a tertiary education but the effects are larger than for offshoring. Doubling the mean level of import competition increases the wages of the employees with tertiary education by 5.5 percent in period $t+2$.

\section{Table 5 here}

The effects are almost the same for those workers who remain employed in the initial firm and those workers who remain employed. Once more, both the workers remaining in the initial firms and those moving to employment in new firms are likely to be a selected sample of all workers hit by trade shocks. Thus, the positive effect of offshoring on wages of both these groups of workers could be due to positive productivity effects of offshoring but also due to the selection of high-skilled workers who remain in the firms.

Panel $\mathrm{C}$ and D in Table 5 show the results for the estimations including the interaction for workers with a production occupation. As in Table 4, the results suggest wage losses for this category of workers even when they remain employed in the initial firm or in some firm. Doubling the mean value of offshoring reduces the wages of the employees

\footnotetext{
${ }^{42}$ The specification with log hourly wage as the dependent variable, including the workers who remain employed in the same firm and estimating the effects in period $t$, is similar to the main specifications in Hummels et al. (2014). However, the magnitude of the estimated effect of offshoring on the log hourly wage of workers with tertiary education is not directly comparable to the results of Hummels et al., since our offshoring variable includes only imports from China and is not in log form. We define the offshoring variable in non-logged form in order to include zero observations in the estimations.

${ }^{43}$ The first-stage estimates are statistically significant and the F-statistics for weak instrument test high (see Table B1 in Appendix B). The results from FE-estimations are not reported but are available upon request.
} 
with production occupation by 1.1 percent in period $t+2$ for the workers who remain employed in the same firm and slightly more for workers who remain employed in some firm. The effect of doubling the mean value of import competition has a slightly larger effect than offshoring; 1.4 percent in period $t+2$ for those workers who remain employed in the same firm. The results for wage outcomes are in line with the results from Hummels et al. (2014) who also find positive wage effects of offshoring for highly skilled workers remaining in the offshoring firms. ${ }^{44}$

\subsection{Other Measures, Outcomes and Specifications}

We have shown that both offshoring and import competition increase the separation probability and the risk of non-employment for all worker types, while the wage effects are modest. In this section, we analyse the sensitivity of our results to different specifications and results.

In the section for employment outcomes, we estimated the effects on two main employment outcome variables; the likelihood of remaining employed in the initial firm and the likelihood of being employed. Our data allows us to distinguish additional employment outcomes among workers switching employers; 1) employment in a different firm in the same manufacturing industry, 2) employment in a different manufacturing industry, and 3) employment in non-manufacturing industry. We also estimate the effects of offshoring and import competition on these employment outcomes also. We find no statistically significant effects, which may be explained by the fact that the shares of workers in these three destinations are small. ${ }^{45}$

The increase in the Chinese import penetration could coincide with other changes in low-income imports that explain the found effects on employment and earnings. For instance, Chinese imports could have crowded out imports from other important lowincome source countries. The descriptive evidence in Section 4 did not suggest any clear

\footnotetext{
${ }^{44}$ Note that the magnitude of the estimated effect of offshoring on the log hourly wage of workers is not directly comparable with the results of Hummels et al., since our offshoring variable only includes imports from China and is not in log-form (does not exclude zero observations).

${ }^{45}$ The mean propabilities for these additional employment outcomes are reported in Table A2 in the Appendix. The estimation results are available upon request.
} 
reallocation of imports from other low-income countries to China, but the evidence showed that there has been a strong increase in the imports from Russia. To check the robustness of the found effects to some other simultaneous changes in imports from low and lowermiddle income countries, we construct measures of offshoring and import competition for low and lower-middle income countries excluding and including China and estimate our main model using these measures. ${ }^{46}$ We use these alternative measures only in the fixed effect estimations, since we do not have a separate instrumental variable for lower-income country imports (see Table A2 for variable descriptives).

In Table B2 in Appendix B, we report the fixed-effect estimation results for a specification including separate measures of offshoring and import competition for Chinese imports and imports from all other lower-income countries. The estimates in Panel A suggest that offshoring to all lower-income countries, including China, is negatively associated with the probability of remaining employed in the same firm, but the estimates are not statistically significant. In Panel B, we include separate measures for offshoring to China and to other low-income countries. The estimates for the offshoring to China measure $\left(C O F F_{i j t}\right)$ are similar to the estimates in Table 1, while offshoring to other low-income countries has a positive sign or is not statistically different from zero.

The estimates in Panel C and D for the import competition measure suggest a similar pattern of results: import competition from all lower-income countries, including China, is negatively associated with the probability of being employed in the same firm, and remaining employed but the estimates are statistically significant only in period $t .{ }^{47}$ When we include separate measures for import competition from China and from all other lowerincome countries, the estimates for the measure of Chinese import competition remain almost unchanged as compared to Table 1 while import competition from other countries has a positive sign or is not statistically different from zero. In sum, these additional results provide further evidence that offshoring to China and import competition from

\footnotetext{
${ }^{46}$ We define the group of low and lower-middle income countries by the definitions of the World Bank for 2001.

${ }^{47}$ Import competition measures for low-income countries (with or without China) are constructed in the same way as $C I P_{i j t}$ measure, deducting firm's own low-income country imports from industry's total low-income country imports and dividing this difference by the sum of industry's total imports and output (see equation 2).
} 
China rather than changes in the imports from other low-income countries explain our main results. Mion and Zhu (2013) also find that China is different from both other lowwage countries and its separate inclusion in the analysis brings out results not found for total imports.

In all models, we have controlled for worker-base year fixed effects. To analyse whether offshoring firms and firms in import competing industries are different, we report the results without individual-base -year-firm (initial job spell) fixed effects. The results reported in Panel A of Table B3 in Appendix B show that workers in firms with a higher level of offshoring have a higher risk of separating from these firms between $t-1$ and $t$, thus indicating that these firms have a higher turnover. When including firm fixed effects, and thus controlling for permanent differences between firms, the negative coefficient becomes smaller and less precise. There is no difference between the results when controlling for firm fixed effects and for firm-individual fixed effects (which is the specification reported in our main tables). Panel B reports the results for import competition. The specification without fixed effects indicates a negative association with import competition and probability of being employed in base-year firm, or in general. When including firm, or firm-individual fixed effects, the results become more negative and significant, indicating that growth in import competition is associated with a higher risk of job loss and nonemployment.

\section{Conclusions}

China's transition to a more market-oriented economy has made a profound change in the world economy and trade. In this paper, we study the consequences of increased Chinese import penetration for employment and earnings of individuals working in the manufacturing sector of a small open economy, namely Finland.

We contribute to the existing literature on employment and earnings effects of importing by distinguishing between the effects of an import shock on final product demand (import competition) and an import shock on the firm's own use of intermediates (offshoring intermediate inputs), and by focusing on worker-level outcomes by worker types. 
To find the causal relationships from import shocks to employment and wages, we exploit the relative increase in Chinese exports to EU following the changes in trade policies between EU and China due to the Chinese WTO entry 2001 and the ending of the quota system due to the Multifiber Arrangement in 2005.

We find that both offshoring and import competition increase the overall probability of an individual leaving her initial employer, and the probability of being non-employed after a separation from the initial firm, but the latter effect is statistically less precise. Distinguishing workers by educational skills shows that the effects of import competition and offshoring on employment are not uniform. Imports from China increase the probability of separation from the initial employer the most for workers with medium and high educational skills, but also for workers with the lowest educational skills. In terms of overall employment, high-skilled workers seem to fare better in the labour market than medium- or low-skilled, as suggested by the smaller effects of offshoring on the risk of non-employment for the high-skilled.

We further scrutinize the impact of importing for workers by occupation. We find that Operators and assemblers face both an increased probability of separation from the initial firm and non-employment caused by offshoring and import competition. Professionals is another occupational group for which firm-level offshoring increases the probablity of leaving the initial firm. However, this group of workers seems to become re-employed in other firms more frequently than production workers as indicated by a considerably smaller risk of non-employment in the short term. Our findings thus suggest that offshoring of jobs that are intensive in routine tasks may have contributed to the polarization of employment by reducing job opportunities in middle-skilled production and operative occupations.

We first focused on employment outcomes arguing that trade shocks are more likely to impact employment rather than earnings in the short run in Finland where wage adjustments are slow but employment protection is relatively weak. Since the employment variables only capture outcomes on the extensive margin, we also use earnings as an outcome variable to capture the adjustments on the intensive margin, both in the number of hours worked and wages. Distinguishing workers by educational skills suggests that offshoring and import competition have a positive effect on the annual labour income and 
the hourly wage of high-skilled workers and a negative effect on the earnings outcomes of the other workers. Further, we find that production workers, who were most adversely affected by offshoring and import competition in terms of employment, also suffer the largest earnings and wage losses due to Chinese imports.

Previous literature suggests that while import competition is expected to crowd out domestic production, the effect of imported intermediates on domestic production is ambiguous. In this paper, we find that both import competition and offshoring increase the risk of separation and non-employment. The results for offshoring are consistent with an increased use of imported intermediates substituting for domestic production which uses medium-skilled workers, in particular for production workers, intensively, thereby causing displacements and lower wages for these workers. However, the results do not exclude the possibility of a productivity effect of offshoring, which could explain the positive effect on the earnings of the high skilled. The findings are consistent with negative substitution and demand effects dominating the wage outcomes for production workers, but the positive wage effect on the high skilled cannot only be accredited to a productivity effect of offshoring since import competition has a similar effect on the wages of the high skilled. Other explanations are provided by Bloom, Draca and Van Reenen (2016) who showed an increased import competition from China to cause an increased technological change within firms and a reallocation of employment towards more technologically advanced firms, leading to a fall in employment for low-skilled workers, and Mion and Zhu (2013) who find industry-level import competition from China to induce skill upgrading in low-tech manufacturing industries. These shifts in the relative demand of skills due to Chinese import competition could explain the positive wage effects for the high skilled that we find in our study. 


\section{References}

[1] Acemoglu, D. and D.H. Autor (2011). "Skills, Tasks and Technologies: Implications for Employment and Earnings." in Handbook of Labor Economics Volume 4, Orley Ashenfelter and David E. Card (eds.), Amsterdam: Elsevier.

[2] Acemoglu D., D. Autor, D. Dorn, G. H. Hanson, B. Price (2016) "Import Competition and the Great U.S. Employment Sag of the 2000s." Journal of Labor Economics, 34(S1), pp. S141-S198.

[3] Ashournia, D., J. Munch and D. Nguyen (2014). "The Impact of Chinese Import Penetration on Danish Firms and Workers." IZA DP No. 8166.

[4] Autor D.H. , D. Dorn and G.H. Hanson (2013). "The China Syndrome: Local Labor Market Effects of Import Competition in the United States." American Economic Review, 103(6), pp. 2121-68.

[5] Autor, D.H., D. Dorn, G.H. Hanson (2015). "Untangling Trade and Technology: Evidence from Local Labor Markets." The Economic Journal, 125 (584), pp. 621-646.

[6] Autor, D. H. , D. Dorn \& G.H. Hanson and J. Song (2014). "Trade Adjustment: Worker-Level Evidence." The Quarterly Journal of Economics, 129(4), pp. 1799-1860.

[7] Balsvik, R., S. Jensen and K.G. Salvanes (2015). "Made in China, Sold in Norway: Local Labor Market Effects of an Import Shock." Journal of Public Economics, 127, pp. $137-144$.

[8] Becker, S.O. , K. Ekholm and M.-A. Muendler (2013). "Offshoring and the onshore composition of tasks and skills." Journal of International Economics, Elsevier, 90(1), pp. $91-106$.

[9] Baumgarten, D., I. Geishecker and H. Görg (2013). "Offshoring, tasks, and the skillwage pattern." European Economic Review, Elsevier, 61(C), pp. 132-152.

[10] Van Beveren, I., A.B. Bernard, and H. Vandenbussche (2012). "Concording EU Trade and Production Data Over Time." Tuck School of Business, mimeo 
[11] Blinder A.S. (2006), "Offshoring: The Next Industrial Revolution" Foreign Affairs 85 (2), pp. 113-128.

[12] Bloom, N., M. Draca J. Van Reenen (2016). "Trade Induced Technical Change? The Impact of Chinese Imports on Innovation, IT and Productivity." Review of Economic Studies, 83(1): pp. 87-117.

[13] Brandt, L., J. Van Biesebroeck, and Y. Zhang (2012). "Creative Accounting or Creative Destruction? Firm-Level Productivity Growth in Chinese Manufacturing." Journal of Development Economics, 97(2), pp. 339-351.

[14] Couch, K. and D. Placzek (2010). "Earnings Impacts of Job Displacement Revisited." American Economic Review 100(1), pp. 572-589.

[15] Dauth, W., Findeisen, S. and Suedekum, J. (2014). "The Rise of the East and the Far East: German Labor Markets and Trade Integration." Journal of the European Economic Association, 12, pp. 1643-1675.

[16] Davis, S.J. and T. Von Wachter (2011) "Recessions and the Costs of Job Loss." Brookings Papers on Economic Activity, Economic Studies Program, The Brookings Institution, 43(2), 1-72.

[17] Ebenstein, A., A. Harrison, M. McMillan and S. Phillips (2014). "Estimating the Impact of Trade and Offshoring on American Workers Using the Current Population Surveys." The Review of Economics and Statistics, 96(3), pp. 581-595.

[18] Ekholm, K. and Hakkala, K. (2006). "The Effect of Offshoring on Labour Demand: Evidence from Sweden." CEPR Discussion Papers 5648, C.E.P.R. Discussion Papers.

[19] Eliason, M. \& D. Storrie (2006). "Lasting or Latent Scars? Swedish Evidence on the Long-Term Effects of Job Displacement." Journal of Labor Economics, University of Chicago Press, 4(4), pp. 831-856, October.

[20] Falk, M. and B. M. Koebel (2002). "Outsourcing, Imports and Labour Demand." Scandinavian Journal of Economics, 104, pp. 567-586. 
[21] Feenstra, R.C. (2004). Advanced International Trade: Theory and Evidence. Princeton, NJ: Princeton University Press.

[22] Feenstra, R.C. and G.H. Hanson (1996). "Globalization, Outsourcing, and Wage Inequality." American Economic Review, 86, pp. 240-45.

[23] Feenstra, R.C. and G.H. Hanson (1999). "The Impact of Outsourcing and HighTechnology Capital on Wages: Estimates for the United States, 1979-1990." The Quarterly Journal of Economics,114, pp. 907-41.

[24] Firpo, S., N.M. Fortin and T. Lemieux (2011). "Occupational Tasks and Changes in the Wage Structure." IZA Discussion Paper No. 5542.

[25] Gorodnichenko, Y., E.G. Mendoza, and L.L. Tesar (2012). "The Finnish Great Depression: From Russia with Love." American Economic Review, 102(4): pp. 1619-44.

[26] Grossman, G. and E. Rossi-Hansberg (2006). "The Rise of Offshoring: It's Not Wine for Cloth Anymore." The New Economic Geography: Effects and Policy Implications. Ed. Federal Reserve Bank of Kansas City.

[27] Grossman, G. and E. Rossi-Hansberg (2008). "Trading Tasks: A Simple Theory of Offshoring." American Economic Review 98(5), pp. 1978-1997.

[28] Hijzen, A. and Görg, H. and R.C. Hine (2005). "International Outsourcing and the Skill Structure of Labor Demand in the United Kingdom." Economic Journal, 115, 506, pp. 860-78.

[29] Hsieh, C.-T., and P.J. Klenow (2009). "Misallocation and Manufacturing TFP in China and India." Quarterly Journal of Economics, 124(4), pp. 1403-1448.

[30] Hsieh, C.-T., and R. Ossa. (2011). "A Global View of Productivity Growth in China.", NBER Working Paper No. 16778.

[31] Hummels, D., R. Jørgensen, J. Munch, and C. Xiang (2014). "The Wage Effects of International Offshoring: Evidence from Danish Matched Worker-Firm Data." American Economic Review, 104(6), pp. 1597-1629. 
[32] Huttunen, K., J. Møen and K. G. Salvanes (2011). "How Destructive is Creative Destruction? Effects of Job Loss on Job Mobility, Withdrawal and Income." Journal of the European Economic Association, 9(5), pp. 840-870.

[33] Huttunen, K. and J. Kellokumpu (2016). "The Effect of Job Displacement on Couples' Fertility Decisions." Journal of Labor Economics,34(2).

[34] Jacobson, Louis S., Robert J. LaLonde and Daniel G. Sullivan (1993). "Earnings Losses of Displaced Workers." American Economic Review, 83(4), pp. 685-709.

[35] Kletzer, L. (2001). Job Loss from Imports: Measuring the Costs, Institute for International Economics, Washington, DC.

[36] Kletzer, L. (2002). Imports, Exports, and Jobs: What does trade mean for employment and job loss?, W.E. Upjohn Institute for Employment Research, Kalamazoo, MI.

[37] Kovak, B., L. Oldenski and N. Sly (2015) "The Labor Market Effects of Offshoring by U.S. Multinational Firms: Evidence from Changes in Global Tax Policies", mimeo.

[38] Leamer, E. and M. Storper (2001), "The Economic Geography of the Internet Age." Journal of International Business Studies 32(4), pp. 641-665.

[39] Levy, F. and R.J. Murmane (2004), The New Division of Labor: How Computers Are Creating the Next Job Market, Princeton and Oxford: Princeton University Press.

[40] Menezes-Filho N.A. , M.-A. Muendler (2011). "Labor Reallocation in Response to Trade Reform." NBER Working Paper No. 17372.

[41] Mion, G. and L. Zhu (2013). "Import competition from and offshoring to China: A curse or blessing for firms?" Journal of International Economics 89, pp. 202-215.

[42] Munch, J.(2010), "Whose Job Goes Abroad? International Outsourcing and Individual Separations." Scandinavian Journal of Economics 112(2), pp. 339-360.

[43] Naughton, B. (2007). The Chinese Economy: Transitions and Growth. Cambridge, MA: MIT Press. 
[44] Strauss-Kahn, V. (2004), "The Role of Globalization in the Within-Industry Shift Away from Unskilled Workers in France." Chapter 6 in R. E. Baldwin and L. A. Winters (eds.), Challenges to Globalization: Analyzing the Economics, NBER Conference Report, University of Chicago Press, Chicago.

[45] Venn, D. (2009). "Legislation, collective bargaining and enforcement: Updating the OECD employment protection indicators." www.oecd.org/els/workingpapers.

[46] Walker, R. (2013). "The Transitional Costs of Sectoral Reallocation: Evidence from the Clean Air Act and the Workforce." The Quarterly Journal of Economics, 128(4), pp. $1787-1835$. 
Figures

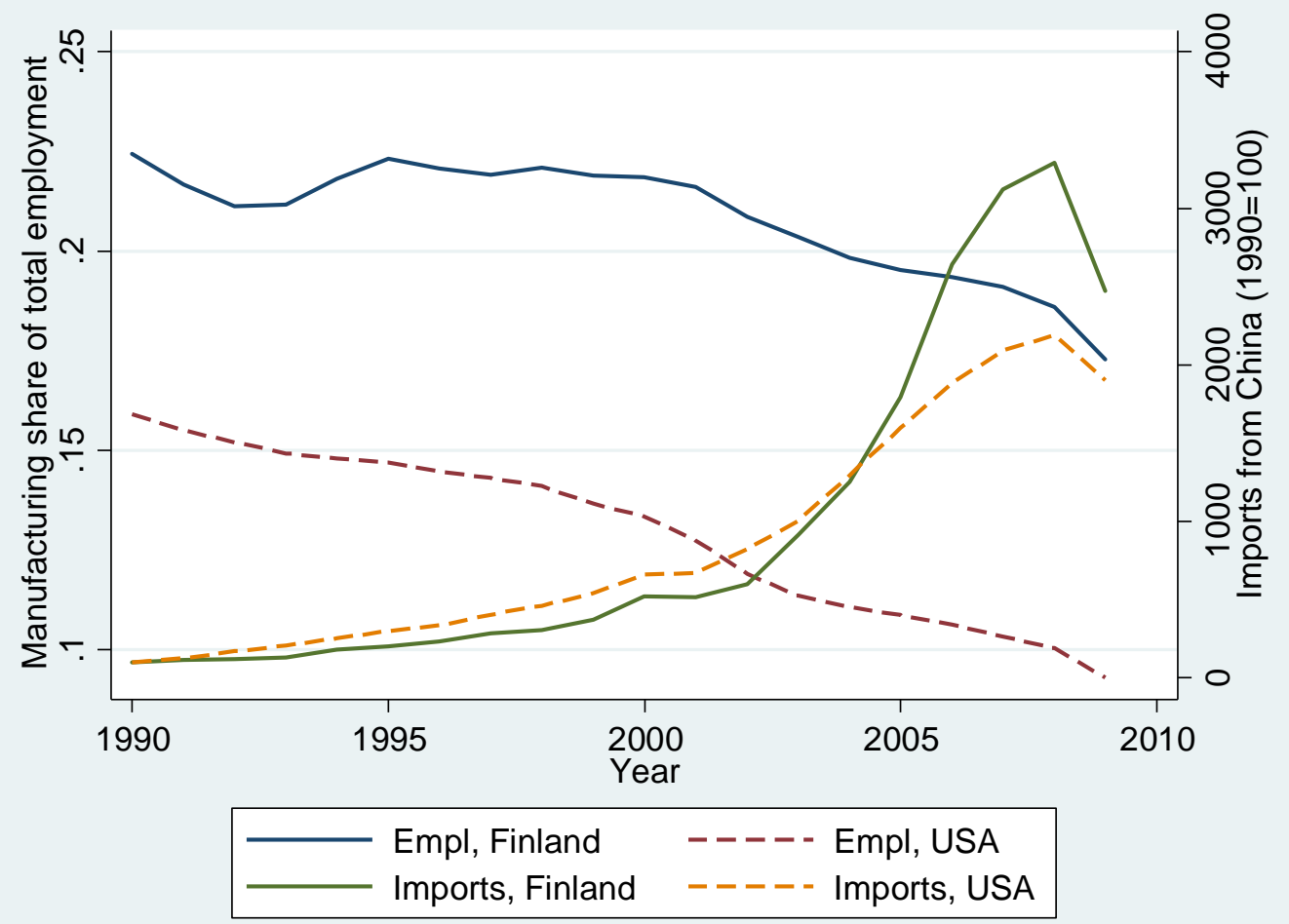

Figure 1. Chinese import penetration and manufacturing employment in Finland and USA 1990-2009.

Source: Computed from OECD Stan database.

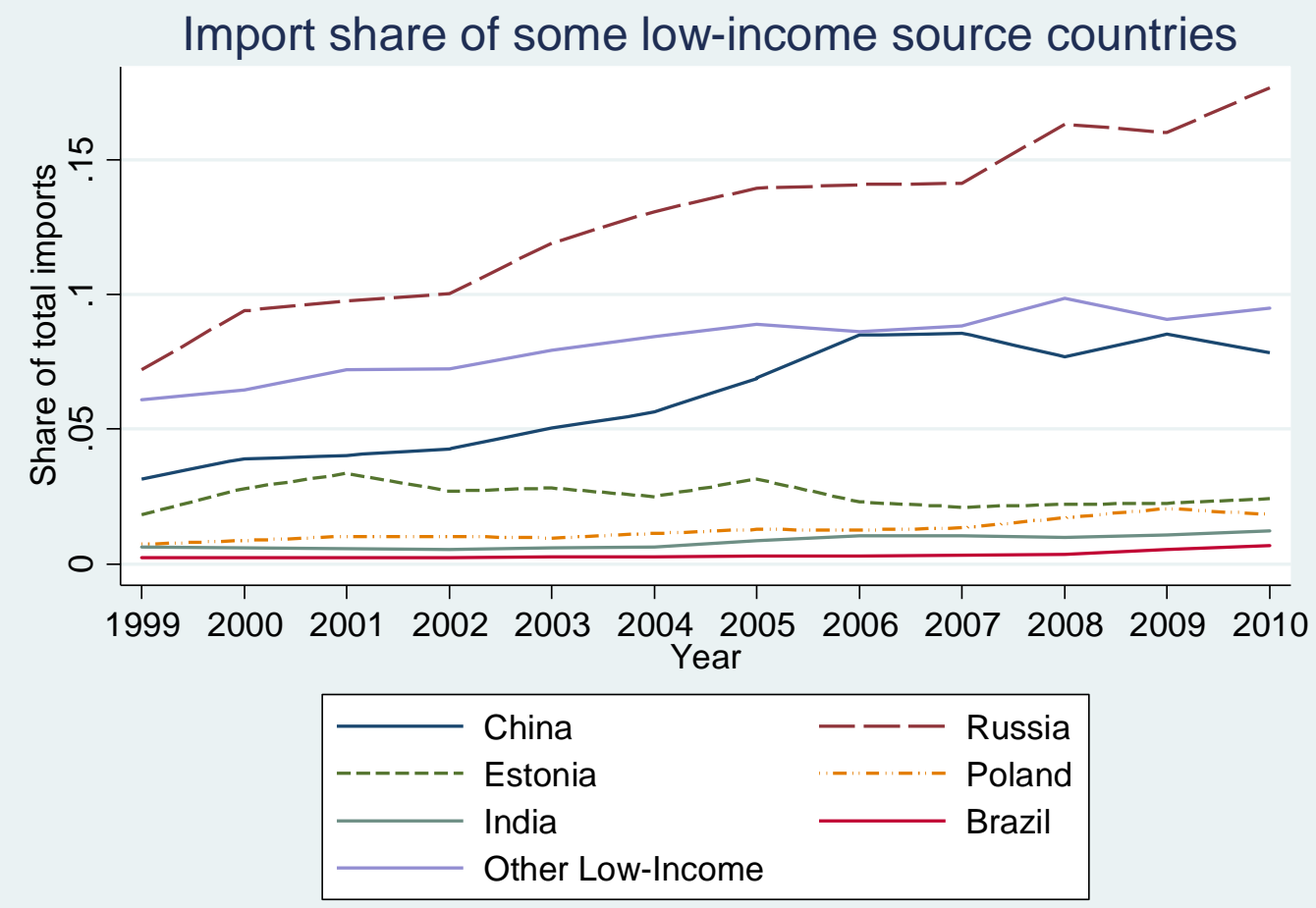

Figure 2. Import shares from the most important low-and middle-income countries.

Source: Computed from data of Finnish Customs. 

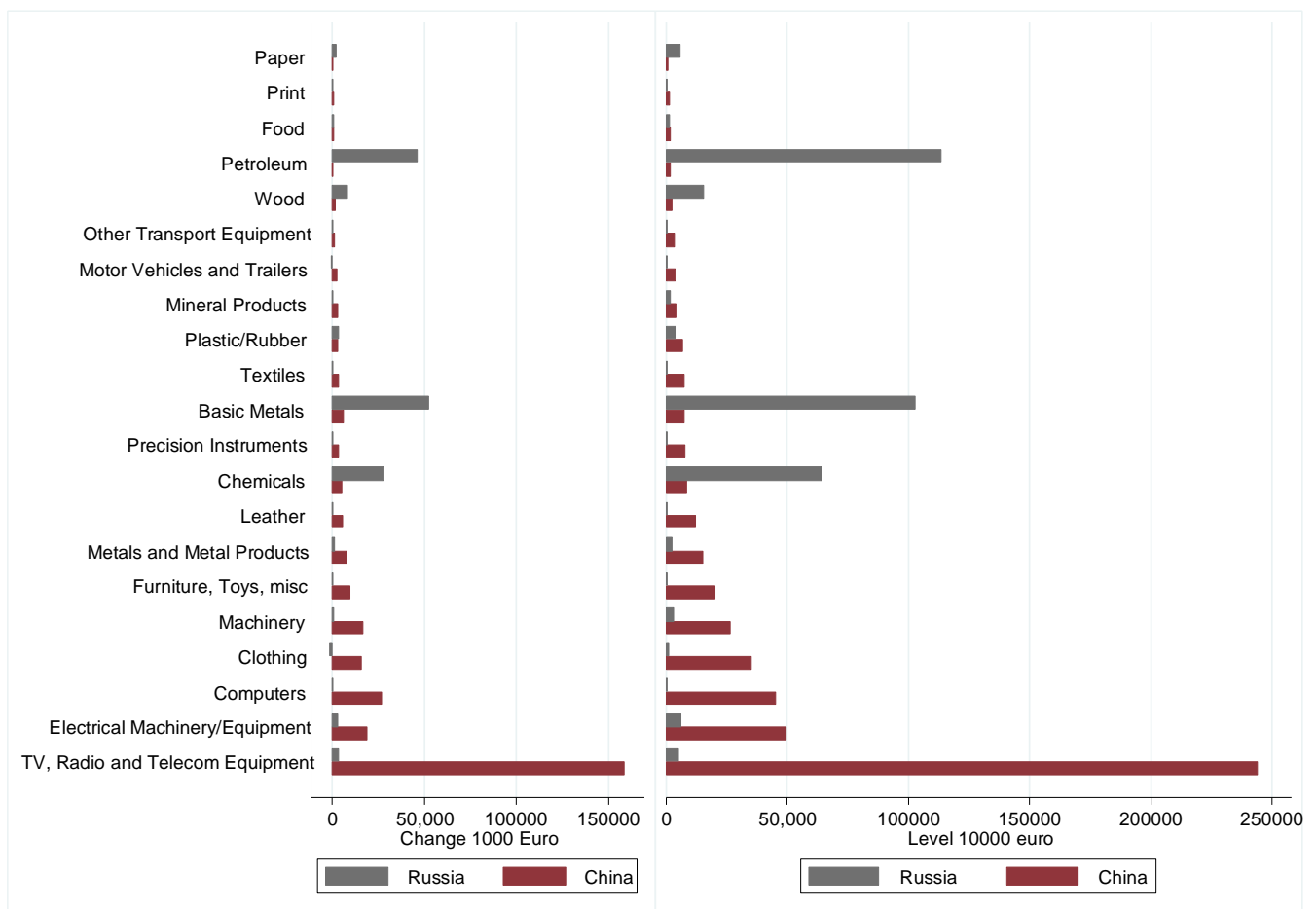

Source: Finnish customs data

Figure 3. Change (2001-2007) and level (2007) of imports from China and Russia by industry.

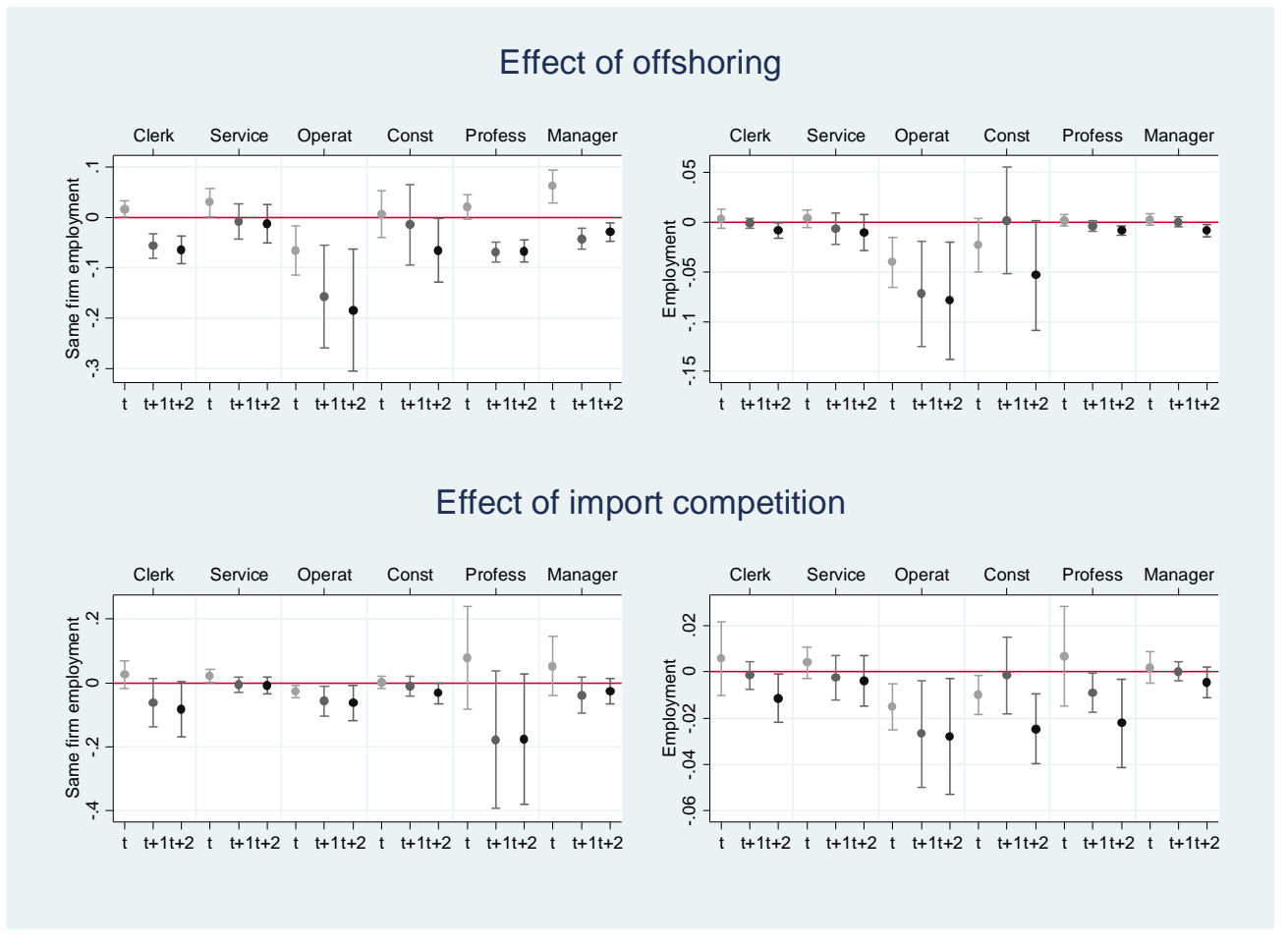

Figure 4. Effect of offshoring or import competition on employment outcomes, by occupation.

Notes: Each panel plots regression coefficients and $90 \%$ confidence intervals obtained from separate IV regressions for each time period and occupational group. The coefficients and standard errors are also reported in table 3. 
Table 1. The effect of offshoring and import competition on employment, FE and FE-IV estimations.

\begin{tabular}{|c|c|c|c|c|c|c|c|c|c|}
\hline \multicolumn{10}{|c|}{$\begin{array}{l}\text { Same firm employment } \\
\end{array}$} \\
\hline FE & (1) & (2) & (3) & FE-IV & (4) & Second & (5) & (6) & (7) \\
\hline Time Period & $\mathrm{t}$ & $t+1$ & $t+2$ & First stage & & stage & $\mathrm{t}$ & $t+1$ & $t+2$ \\
\hline \multicolumn{10}{|l|}{ PANEL A } \\
\hline $\mathrm{COFF}_{\mathrm{ijt}}$ & $\begin{array}{l}-0.0063 \\
(0.005)\end{array}$ & $\begin{array}{l}-0.0150 \\
(0.009)\end{array}$ & $\begin{array}{l}-0.0110^{*} \\
(0.006)\end{array}$ & CRES_INP $_{\mathrm{jt}}$ & $\begin{array}{l}14.8173^{* * *} \\
(3.353)\end{array}$ & $\mathrm{COFF}_{\mathrm{ijt}}$ & $\begin{array}{l}0.0018 \\
(0.016)\end{array}$ & $\begin{array}{l}-0.0711^{* * *} \\
(0.019)\end{array}$ & $\begin{array}{l}-0.0768^{* * *} \\
(0.025)\end{array}$ \\
\hline R-squared & 0.103 & 0.175 & 0.221 & & 0.1649 & & 0.1022 & 0.1441 & 0.1835 \\
\hline \multicolumn{10}{|l|}{ PANEL B } \\
\hline $\mathrm{CIP}_{\mathrm{ijt}}$ & $\begin{array}{l}-0.0079^{* *} \\
(0.003)\end{array}$ & $\begin{array}{l}-0.0069 * \\
(0.004)\end{array}$ & $\begin{array}{l}-0.0036 \\
(0.004)\end{array}$ & CRES_IND ${ }_{\mathrm{jt}}$ & $\begin{array}{l}13.8353^{* *} \\
(5.569)\end{array}$ & $\mathrm{CIP}_{\mathrm{ijt}}$ & $\begin{array}{l}0.0032 \\
(0.019)\end{array}$ & $\begin{array}{l}-0.0714^{*} \\
(0.041)\end{array}$ & $\begin{array}{l}-0.0774 * \\
(0.040)\end{array}$ \\
\hline R-squared & 0.104 & 0.173 & 0.221 & & 0.124 & & 0.1012 & 0.1093 & 0.1453 \\
\hline \multicolumn{10}{|l|}{ PANEL C } \\
\hline $\mathrm{COFF}_{\mathrm{ijt}}$ & $\begin{array}{l}-0.0054 \\
(0.005)\end{array}$ & $\begin{array}{l}-0.0143 \\
(0.009)\end{array}$ & $\begin{array}{l}-0.0106^{*} \\
(0.006)\end{array}$ & & & & & & \\
\hline CIP $_{\mathrm{ijt}}$ & $\begin{array}{l}-0.0075^{* *} \\
(0.003)\end{array}$ & $\begin{array}{l}-0.0059 \\
(0.004)\end{array}$ & $\begin{array}{l}-0.0028 \\
(0.004)\end{array}$ & & & & & & \\
\hline R-squared & 0.104 & 0.175 & 0.222 & & & & & & \\
\hline \multicolumn{10}{|c|}{ Employment } \\
\hline FE & (1) & (2) & (3) & FE-IV & (4) & Second & (5) & (6) & (7) \\
\hline Time Period & $\mathrm{t}$ & $t+1$ & $t+2$ & First stage & COFF & stage & $\mathrm{t}$ & $t+1$ & $t+2$ \\
\hline \multicolumn{10}{|l|}{ PANEL D } \\
\hline $\mathrm{COFF}_{\mathrm{ijt}}$ & $\begin{array}{l}0.0009 \\
(0.001)\end{array}$ & $\begin{array}{l}-0.0019 \\
(0.002)\end{array}$ & $\begin{array}{l}-0.0012 \\
(0.001)\end{array}$ & CRES_INP $_{\mathrm{it}}$ & $\begin{array}{l}14.8173^{* * *} \\
(3.353)\end{array}$ & $\mathrm{COFF}_{\mathrm{ijt}}$ & $\begin{array}{l}-0.0034 \\
(0.008)\end{array}$ & $\begin{array}{l}-0.0117 \\
(0.012)\end{array}$ & $\begin{array}{l}-0.0186 \\
(0.015)\end{array}$ \\
\hline R-squared & 0.041 & 0.037 & 0.051 & & 0.1649 & & 0.0401 & 0.0340 & 0.0441 \\
\hline \multicolumn{10}{|l|}{ PANEL E } \\
\hline $\mathrm{CIP}_{\mathrm{ijt}}$ & $\begin{array}{l}-0.0028 * * * \\
(0.001)\end{array}$ & $\begin{array}{l}-0.0023 * * \\
(0.001)\end{array}$ & $\begin{array}{l}-0.0015 \\
(0.001)\end{array}$ & CRES_IND $_{\text {it }}$ & $\begin{array}{l}13.8353 * * \\
(5.569)\end{array}$ & $\mathrm{CIP}_{\mathrm{ijt}}$ & $\begin{array}{l}-0.0032 \\
(0.006)\end{array}$ & $\begin{array}{l}-0.0116 \\
(0.008)\end{array}$ & $\begin{array}{l}-0.0184 * * \\
(0.009)\end{array}$ \\
\hline R-squared & 0.041 & 0.037 & 0.051 & & 0.124 & & 0.0412 & 0.0330 & 0.0409 \\
\hline \multicolumn{10}{|l|}{ PANEL $F$} \\
\hline $\mathrm{COFF}_{\mathrm{ijt}}$ & $\begin{array}{l}0.0013 \\
(0.001)\end{array}$ & $\begin{array}{l}-0.0017 \\
(0.002)\end{array}$ & $\begin{array}{l}-0.0011 \\
(0.001)\end{array}$ & & & & & & \\
\hline $\mathrm{CIP}_{\mathrm{ijt}}$ & $\begin{array}{l}-0.0029 * * * \\
(0.001)\end{array}$ & $\begin{array}{l}-0.0021^{* *} \\
(0.0011)\end{array}$ & $\begin{array}{l}-0.0014 \\
(0.001)\end{array}$ & & & & & & \\
\hline R-squared & 0.041 & 0.037 & 0.051 & & & & & & \\
\hline Observations & $1,511,201$ & $1,511,201$ & $1,511,201$ & & $1,511,201$ & & $1,511,201$ & $1,511,201$ & $1,511,201$ \\
\hline $\begin{array}{l}\text { No of worker-firm } \\
\text { fe }\end{array}$ & 344,866 & 344,866 & 344,866 & & 344,866 & & 344,866 & 344,866 & 344,866 \\
\hline $\begin{array}{l}\text { Notes: Columns 1-3 p } \\
\mathrm{t}-1 \text { or any employmen } \\
\text { competition is instrum } \\
\text { of children under } 18 \text { ( } \\
\text { Robust standard error }\end{array}$ & $\begin{array}{l}\text { ent the results } \mathrm{fr} \\
\text { dependent vari } \\
\text { ed by using Chi } \\
\text { interaction wit } \\
\text { ustered at base- }\end{array}$ & $\begin{array}{l}\text { m separate w } \\
\text { bles. China o } \\
\text { na export supp } \\
\text { female), age, } \\
\text { eer-firm level }\end{array}$ & $\begin{array}{l}\text { ker-level FE r } \\
\text { horing (COFl } \\
\text { (CRES-IND } \\
\mathrm{e}^{2} \text {, tenure }(2 \text {, } \\
\text { e reported in }\end{array}$ & $\begin{array}{l}\text { essions and colu } \\
\text { instrumented by } \\
\text { All specifications } \\
4-10,>10 \text { years) } \\
\text { entheses.*** } p<(\end{array}$ & $\begin{array}{l}\text { 5-7 from separ } \\
\text { ing China expor } \\
\text { lude control var } \\
\text { log firm size in } \\
, * * p<0.05, * p\end{array}$ & $\begin{array}{l}\text { FE-IV regr } \\
\text { pply weigh } \\
\text { es: number } \\
\text { iod t-1. Ind }\end{array}$ & $\begin{array}{l}\text { using either e } \\
\text { input structu } \\
\text { dren under } 7 \text { ( } \\
\text { base-year-fir }\end{array}$ & $\begin{array}{l}\text { oyment in the sa } \\
\text { RES-INP }{ }_{\mathrm{j}} \text { ) and } \\
\text { an interaction } \mathrm{w} \\
\text { d year fixed effe }\end{array}$ & $\begin{array}{l}\text { firm as in perio } \\
\text { ina import } \\
\text { female), numbe } \\
\text { are included. }\end{array}$ \\
\hline
\end{tabular}


Table 2. The effect of offshoring and import competition on employment by education, FE and FE-IV estimations.

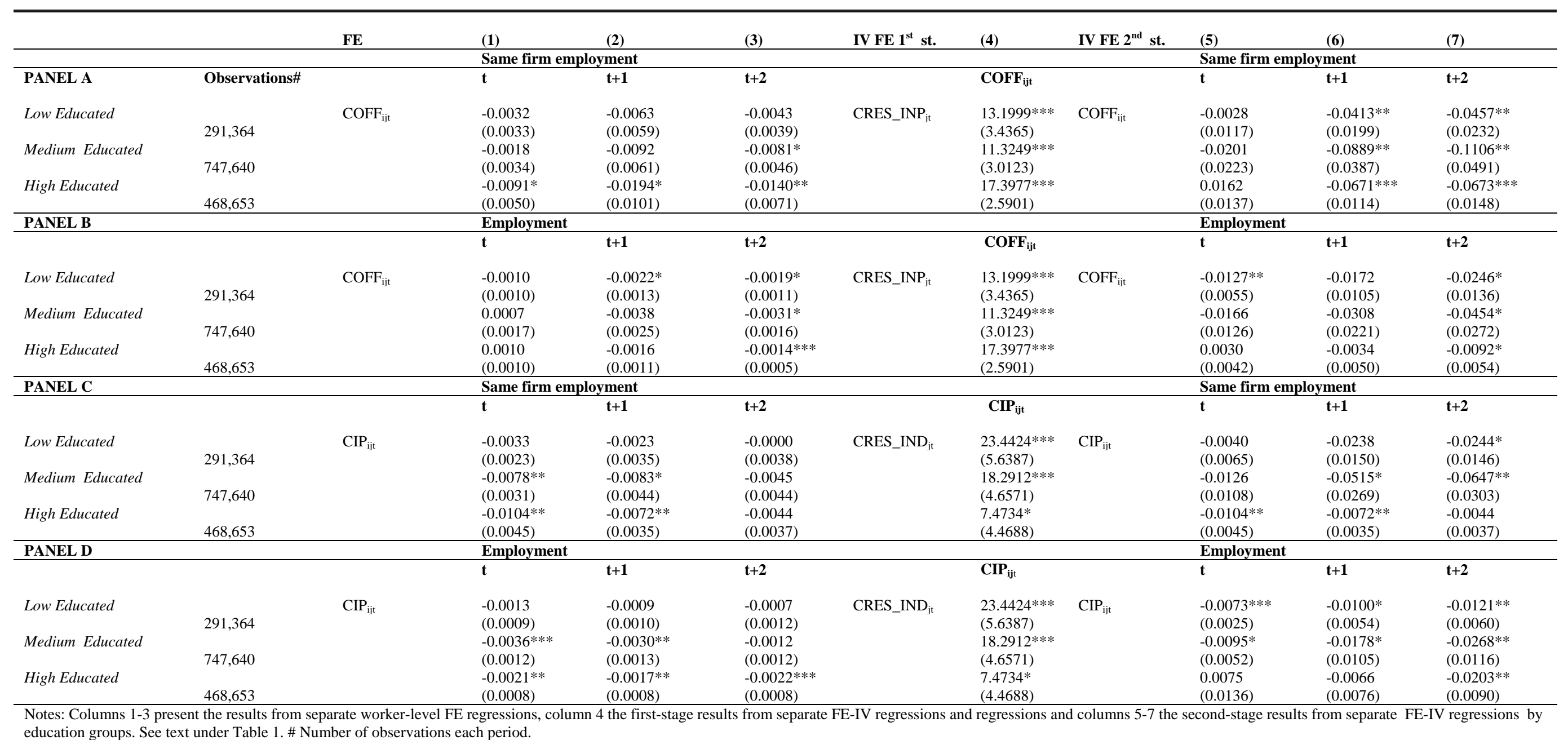

Notes: Columns 1-3 present the results from separate worker-level FE regressions,
education groups. See text under Table 1 . \# Number of observations each period. 
Table 3. The effect of offshoring and import competition on employment by occupation, FE and FE-IV estimations.

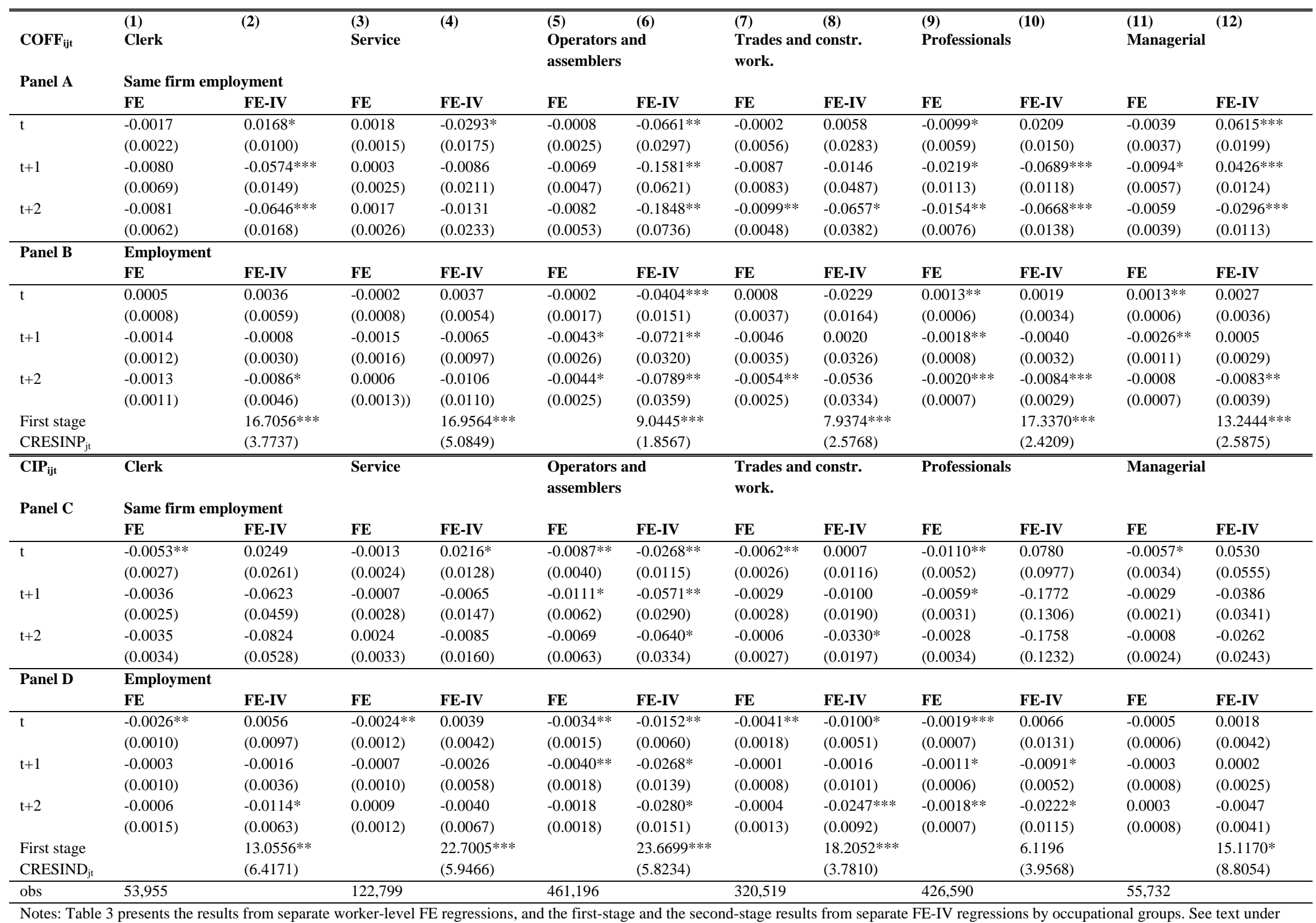

Table 
Table 4. The effect of offshoring and import competition on annual labor income, FE and FE-IV estimations.

\begin{tabular}{|c|c|c|c|c|c|c|}
\hline & (1) & (2) & (3) & (4) & (5) & (6) \\
\hline & \multicolumn{3}{|c|}{$\mathrm{FE}$} & \multicolumn{3}{|c|}{ FE-IV } \\
\hline & $\mathrm{t}$ & $t+1$ & $t+2$ & $\mathrm{t}$ & $t+1$ & $t+2$ \\
\hline \multicolumn{7}{|l|}{$\begin{array}{l}\text { TIme Period } \\
\text { PANEL A }\end{array}$} \\
\hline $\mathrm{COFF}_{\mathrm{ijt}}$ & $\begin{array}{l}207.2764 \\
(137.145)\end{array}$ & $\begin{array}{l}199.6352 \\
(166.070)\end{array}$ & $\begin{array}{l}134.3398 \\
(130.942)\end{array}$ & $\begin{array}{l}83.9413 \\
(153.274)\end{array}$ & $\begin{array}{l}609.2829 \\
(572.012)\end{array}$ & $\begin{array}{l}41.6512 \\
(708.330)\end{array}$ \\
\hline \multicolumn{7}{|l|}{ PANEL B } \\
\hline $\mathrm{CIP}_{\mathrm{ijt}}$ & $\begin{array}{l}-20.7707 \\
(34.961)\end{array}$ & $\begin{array}{l}-118.0665 * * \\
(50.079)\end{array}$ & $\begin{array}{l}-91.2247^{* *} \\
(42.631)\end{array}$ & $\begin{array}{l}104.9369 \\
(144.629)\end{array}$ & $\begin{array}{l}623.3480 \\
(923.044) \\
\end{array}$ & $\begin{array}{l}-55.5624 \\
(715.811)\end{array}$ \\
\hline \multicolumn{7}{|l|}{ PANEL C } \\
\hline $\mathrm{COFF}_{\mathrm{ijt}}$ & $\begin{array}{l}-22.2425 \\
(37.406)\end{array}$ & $\begin{array}{l}-57.8619 \\
(53.063)\end{array}$ & $\begin{array}{l}-71.8127 \\
(51.844)\end{array}$ & $\begin{array}{l}-1,097.4325^{* * *} \\
(418.621)\end{array}$ & $\begin{array}{l}-1,066.8240 \\
(876.272)\end{array}$ & $\begin{array}{l}-1,687.3332 * \\
(975.865)\end{array}$ \\
\hline $\mathrm{COFF}_{\mathrm{ijt}} *$ Tertiary edu & $\begin{array}{l}487.8933 * * \\
(211.392)\end{array}$ & $\begin{array}{l}549.7088^{*} \\
(285.826)\end{array}$ & $\begin{array}{l}440.2913 * * \\
(199.673)\end{array}$ & $\begin{array}{l}1,928.3605^{*} \\
(986.713)\end{array}$ & $\begin{array}{l}2,750.1957 * * * \\
(934.756)\end{array}$ & $\begin{array}{l}2,839.7766^{* * * *} \\
(841.974)\end{array}$ \\
\hline \multicolumn{7}{|l|}{ PANEL D } \\
\hline $\mathrm{CIP}_{\mathrm{ijt}}$ & $\begin{array}{l}-153.2507^{* * *} \\
(37.304)\end{array}$ & $\begin{array}{l}-225.6320^{* * *} \\
(64.460)\end{array}$ & $\begin{array}{l}-164.3371^{* * *} \\
(44.977)\end{array}$ & $\begin{array}{l}-521.3241^{* * *} \\
(133.259)\end{array}$ & $\begin{array}{l}-394.1836 \\
(445.607)\end{array}$ & $\begin{array}{l}-889.1387 * * \\
(394.288)\end{array}$ \\
\hline $\mathrm{CIP}_{\mathrm{ijt}} *$ Tertiary edu & $\begin{array}{l}463.4259^{* * *} \\
(154.739)\end{array}$ & $\begin{array}{l}376.7264^{* * * *} \\
(97.023)\end{array}$ & $\begin{array}{l}255.9808^{* * * *} \\
(57.393)\end{array}$ & $\begin{array}{l}2,296.0869 * * * \\
(345.032)\end{array}$ & $\begin{array}{l}3,772.0022 * * \\
(1,891.445)\end{array}$ & $\begin{array}{l}3,091.7893 * \\
(1,682.564)\end{array}$ \\
\hline Observations & $1,511,201$ & $1,511,201$ & $1,511,201$ & $1,511,201$ & $1,511,201$ & $1,511,201$ \\
\hline \multicolumn{7}{|l|}{ PANEL E } \\
\hline $\mathrm{COFF}_{\mathrm{ijt}}$ & $\begin{array}{l}140.5644 \\
(104.767)\end{array}$ & $\begin{array}{l}132.6768 \\
(89.057)\end{array}$ & $\begin{array}{l}148.2672^{* *} \\
(71.178)\end{array}$ & $\begin{array}{l}-284.0437 \\
(264.692)\end{array}$ & $\begin{array}{l}1.7265 \\
(526.196)\end{array}$ & $\begin{array}{l}-468.2525 \\
(467.339)\end{array}$ \\
\hline $\mathrm{COFF}_{\mathrm{ijt}} *$ Tertiary edu & $\begin{array}{l}345.2100^{* *} \\
(143.869)\end{array}$ & $\begin{array}{l}\text { 411.8819* } \\
(223.881)\end{array}$ & $\begin{array}{l}300.1357 * \\
(175.319)\end{array}$ & $\begin{array}{l}1,190.4494 \\
(862.552)\end{array}$ & $\begin{array}{l}1,926.1872^{* * *} \\
(679.560)\end{array}$ & $\begin{array}{l}1,944.3885 * * * \\
(471.663)\end{array}$ \\
\hline \multirow{2}{*}{$\begin{array}{l}\mathrm{COFF}_{\mathrm{ijt}} * \text { Production } \\
\text { occ }\end{array}$} & $-258.9288^{*}$ & $-235.9597 *$ & $-217.2282 * * *$ & $-1,297.7252^{* * *}$ & $-1,310.6143^{* * *}$ & $-1,200.3711^{* * *}$ \\
\hline & (138.859) & (131.301) & (71.388) & $(204.8890)$ & $(259.0446)$ & $(379.9345)$ \\
\hline \multicolumn{7}{|l|}{ PANEL F } \\
\hline CIP $_{\mathrm{ijt}}$ & $\begin{array}{l}-22.3239 \\
(25.434)\end{array}$ & $\begin{array}{l}-87.3600 * * \\
(37.931)\end{array}$ & $\begin{array}{l}-68.0553 * * \\
(31.753)\end{array}$ & $\begin{array}{l}-41.4781 \\
(138.524)\end{array}$ & $\begin{array}{l}393.0681 \\
(692.160)\end{array}$ & $\begin{array}{l}-102.4876 \\
(434.450)\end{array}$ \\
\hline $\mathrm{CIP}_{\mathrm{ijt}} *$ Tertiary edu & $\begin{array}{l}385.0827 * * * \\
(135.513)\end{array}$ & $\begin{array}{l}307.3921^{* * *} \\
(82.114)\end{array}$ & $\begin{array}{l}217.8426 * * * \\
(51.230)\end{array}$ & $\begin{array}{l}1,924.7112^{* * * *} \\
(340.671)\end{array}$ & $\begin{array}{l}3,451.7624 * * \\
(1,746.314)\end{array}$ & $\begin{array}{l}2,907.3849 * \\
(1,673.105)\end{array}$ \\
\hline $\mathrm{CIP}_{\mathrm{ijt}} *$ Production occ & $\begin{array}{l}-125.3086^{* * *} \\
(36.131)\end{array}$ & $\begin{array}{l}-128.9670^{* * * *} \\
(29.257)\end{array}$ & $\begin{array}{l}-86.7801^{* * * *} \\
(22.678)\end{array}$ & $\begin{array}{l}-497.2043^{* * * *} \\
(157.968)\end{array}$ & $\begin{array}{l}-655.1439 * * \\
(313.447)\end{array}$ & $\begin{array}{l}-503.0991 * * * \\
(188.794)\end{array}$ \\
\hline Observations & $1,507,854$ & $1,503,798$ & $1,500,232$ & $1,506,766$ & $1,502,592$ & $1,498,998$ \\
\hline
\end{tabular}


Table 5. The effect of offshoring and import competition on (log) hourly wage, FE-IV estimations.

\begin{tabular}{|c|c|c|c|c|c|c|}
\hline & (1) & $(2)$ & (3) & (4) & (5) & $(6)$ \\
\hline & \multicolumn{3}{|c|}{ Employed in the same firm } & \multicolumn{3}{|c|}{ Employed } \\
\hline Time Period & $\mathrm{t}$ & $\mathrm{t}+1$ & $t+2$ & $\mathrm{t}$ & $t+1$ & $t+2$ \\
\hline \multicolumn{7}{|l|}{ Panel A } \\
\hline $\mathrm{COFF}_{\mathrm{ijt}}$ & $\begin{array}{l}-0.0092 * * * \\
(0.0033)\end{array}$ & $\begin{array}{l}-0.0129 * * \\
(0.0051)\end{array}$ & $\begin{array}{l}-0.0123 \\
(0.0077)\end{array}$ & $\begin{array}{l}-0.0102 * * * \\
(0.0033)\end{array}$ & $\begin{array}{l}-0.0150 * * * \\
(0.0056)\end{array}$ & $\begin{array}{l}-0.0126 \\
(0.0096)\end{array}$ \\
\hline $\mathrm{COFF}_{\mathrm{ijt}} *$ Tertiary edu & $\begin{array}{l}0.0108^{* *} \\
(0.0048)\end{array}$ & $\begin{array}{l}0.0195^{*} \\
(0.0104)\end{array}$ & $\begin{array}{l}0.0254^{* *} \\
(0.0105)\end{array}$ & $\begin{array}{l}0.0118^{* *} \\
(0.0053)\end{array}$ & $\begin{array}{l}0.0197^{*} \\
(0.0106)\end{array}$ & $\begin{array}{l}0.0254^{* *} \\
(0.0119)\end{array}$ \\
\hline \multicolumn{7}{|l|}{ Panel B } \\
\hline $\mathrm{CIP}_{\mathrm{ijt}}$ & $\begin{array}{l}-0.0063 \\
(0.0048)\end{array}$ & $\begin{array}{l}-0.0082^{*} \\
(0.0042)\end{array}$ & $\begin{array}{l}-0.0075 \\
(0.0048)\end{array}$ & $\begin{array}{l}-0.0070 \\
(0.0048)\end{array}$ & $\begin{array}{l}-0.0107 * * \\
(0.0047)\end{array}$ & $\begin{array}{l}-0.0064 \\
(0.0064)\end{array}$ \\
\hline $\mathrm{CIP}_{\mathrm{ijt}} *$ Tertiary edu & $\begin{array}{l}0.0187 * * \\
(0.0094)\end{array}$ & $\begin{array}{l}0.0365^{* * *} \\
(0.0097)\end{array}$ & $\begin{array}{l}0.0517 * * * \\
(0.0187)\end{array}$ & $\begin{array}{l}0.0191^{* *} \\
(0.0086)\end{array}$ & $\begin{array}{l}0.0361 * * * \\
(0.0089)\end{array}$ & $\begin{array}{l}0.0586 * * * \\
(0.0213)\end{array}$ \\
\hline Observations & 980,061 & 868,418 & 747,677 & $1,024,069$ & 978,851 & 932,902 \\
\hline $\begin{array}{l}\text { No of worker-firm fixed } \\
\text { effects }\end{array}$ & 229,615 & 209,041 & 180,424 & 239,090 & 232,259 & 224,663 \\
\hline \multicolumn{7}{|l|}{ Panel C } \\
\hline $\mathrm{COFF}_{\mathrm{ijt}}$ & $\begin{array}{l}-0.0044 \\
(0.0029)\end{array}$ & $\begin{array}{l}-0.0049 \\
(0.0036)\end{array}$ & $\begin{array}{l}-0.0040 \\
(0.0043)\end{array}$ & $\begin{array}{l}-0.0052^{*} \\
(0.0029)\end{array}$ & $\begin{array}{l}-0.0064^{* *} \\
(0.0030)\end{array}$ & $\begin{array}{l}-0.0028 \\
(0.0048)\end{array}$ \\
\hline $\mathrm{COFF}_{\mathrm{ijt}} *$ Tertiary edu & $\begin{array}{l}0.0063^{*} \\
(0.0035)\end{array}$ & $\begin{array}{l}0.0120^{*} \\
(0.0071)\end{array}$ & $\begin{array}{l}0.0175^{* * *} \\
(0.0067)\end{array}$ & $\begin{array}{l}0.0071^{*} \\
(0.0037)\end{array}$ & $\begin{array}{l}0.0116^{* *} \\
(0.0068)\end{array}$ & $\begin{array}{l}0.0161 * * \\
(0.0071)\end{array}$ \\
\hline $\mathrm{COFF}_{\mathrm{ijt}}{ }^{*}$ Production occ. & $\begin{array}{l}-0.0106 * * * \\
(0.0023)\end{array}$ & $\begin{array}{l}-0.0182 * * * \\
(0.0053)\end{array}$ & $\begin{array}{l}-0.0201 * * * \\
(0.0068)\end{array}$ & $\begin{array}{l}-0.0114 * * * \\
(0.0024)\end{array}$ & $\begin{array}{l}-0.0203^{* * *} \\
(0.0062)\end{array}$ & $\begin{array}{l}-0.0237 * * * \\
(0.0084)\end{array}$ \\
\hline \multicolumn{7}{|l|}{ Panel D } \\
\hline $\mathrm{CIP}_{\mathrm{ijt}}$ & $\begin{array}{l}-0.0028 \\
(0.0046)\end{array}$ & $\begin{array}{l}-0.0012 \\
(0.0035)\end{array}$ & $\begin{array}{l}0.0010 \\
(0.0057)\end{array}$ & $\begin{array}{l}-0.0031 \\
(0.0045)\end{array}$ & $\begin{array}{l}-0.0028 \\
(0.0038)\end{array}$ & $\begin{array}{l}0.0047 \\
(0.0091)\end{array}$ \\
\hline $\mathrm{CIP}_{\mathrm{ijt}} *$ Tertiary edu & $\begin{array}{l}0.0158^{*} \\
(0.0092)\end{array}$ & $\begin{array}{l}0.0307^{* * *} \\
(0.0094)\end{array}$ & $\begin{array}{l}0.0448^{* * * *} \\
(0.0165)\end{array}$ & $\begin{array}{l}0.0159^{*} \\
(0.0084)\end{array}$ & $\begin{array}{l}0.0297^{* * * *} \\
(0.0086)\end{array}$ & $\begin{array}{l}0.0497 * * * \\
(0.0183)\end{array}$ \\
\hline $\mathrm{CIP}_{\mathrm{ijt}}{ }^{*}$ Production occ. & $\begin{array}{l}-0.0048^{* * *} \\
(0.0015)\end{array}$ & $\begin{array}{l}-0.0097 * * * \\
(0.0021)\end{array}$ & $\begin{array}{l}-0.0119 * * * \\
(0.0039)\end{array}$ & $\begin{array}{l}-0.0053^{* * *} \\
(0.0016)\end{array}$ & $\begin{array}{l}-0.0109 * * * \\
(0.0025)\end{array}$ & $\begin{array}{l}-0.0153^{* * *} \\
(0.0056)\end{array}$ \\
\hline Observations & 980,061 & 868,418 & 747,677 & $1,024,069$ & 978,851 & 932,902 \\
\hline
\end{tabular}

Notes: Columns 1-3 present the results from separate worker-level FE regressions and columns 4-6 the results from the second-stage FE-IV regressions, using log hourly wage as a dependent variable. The first-stage results are reported in Table B5 in Appendix B. All specifications include the same

control variables as in Table 1 . Individual-base-year-firm and year fixed effects are included. Offshoring $\left(\mathrm{COFF}_{\mathrm{ijt}}\right)$ is instrumented using China export

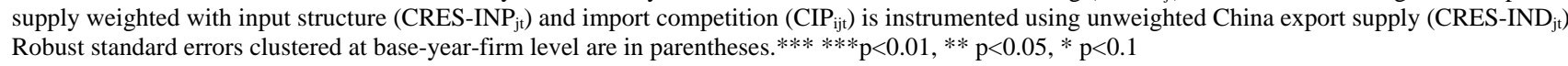




\section{Appendix A}

Table A1. Firm-level FE estimations.

\begin{tabular}{lllllll}
\hline \hline & $(1)$ & $(2)$ & $(3)$ & $(4)$ & $(5)$ & $(6)$ \\
\hline Variable & $\log (\mathrm{empl})$ & $\log (\mathrm{sales})$ & export share & $\begin{array}{l}\text { high-skilled } \\
\text { share }\end{array}$ & $\begin{array}{l}\text { medium- } \\
\text { skilled share }\end{array}$ & $\begin{array}{l}\text { low-skilled } \\
\text { share }\end{array}$ \\
\hline COFFijt & -0.0001 & $-0.0149^{* * *}$ & -0.0011 & 0.00004 & 0.00004 & -0.0008 \\
& $(0.001)$ & $(0.005)$ & $(0.001)$ & $(0.0003)$ & $(0.0003)$ & $(0.0002)$ \\
R-squared & 0.009 & 0.009 & 0.019 & 0.014 & 0.014 & 0.076 \\
Observations & 20,484 & 20,484 & 20,484 & 20,484 & 20,484 & 20,484 \\
No of firms & 3,882 & 3,882 & 3,882 & 3,882 & 3,882 & 3,882 \\
\hline $\mathrm{CIP}_{\text {ijt }}$ & $-0.0116^{* * *}$ & $-0.0137^{* * *}$ & -0.0004 & -0.0002 & -0.0005 & 0.0002 \\
& $(0.003)$ & $(0.004)$ & $(0.0010)$ & $(0.0005)$ & $(0.0005)$ & $(0.0004)$ \\
R-squared & 0.011 & 0.090 & 0.019 & 0.026 & 0.014 & 0.076 \\
Observations & 20,484 & 20,484 & 20,484 & 20,484 & 20,484 & 20,484 \\
No of firms & 3,882 & 3,882 & 3,882 & 3,882 & 3,882 & 3,882 \\
\hline
\end{tabular}

Notes: All specifications include year and firm fixed effects. Robust standard errors clustered at firm level are in parentheses. $* * * \mathrm{p}<0.01, * * \mathrm{p}<0.05, * \mathrm{p}<0.1$ 
Table A2. Summary statistics: mean values for individual level analysis

\begin{tabular}{|c|c|c|c|c|}
\hline \multirow[t]{2}{*}{ Outcome Variables } & \multirow[t]{2}{*}{ Variable } & \multicolumn{3}{|c|}{ Time Period } \\
\hline & & $t$ & $t+1$ & $t+2$ \\
\hline \multirow[t]{7}{*}{ All Employees } & Employed t-1 period firm & .9205 & .8162 & .7152 \\
\hline & Employed & .9688 & .9397 & .9120 \\
\hline & - different firm, same manufact. industry & .0176 & .0550 & .0947 \\
\hline & - different manufacturing industry & .0098 & .0241 & .0364 \\
\hline & - non-manufacturing & .0208 & .0445 & .0657 \\
\hline & Annual earnings (real value) & 35023.44 & 35027.84 & 34805.84 \\
\hline & Log hourly wage* & 16.3749 & 16.8094 & 17.2609 \\
\hline \multirow[t]{5}{*}{ Lower Secondary } & Employed t-1 period firm & .9253 & .8196 & .7112 \\
\hline & Employed & .9605 & .9170 & .8736 \\
\hline & Annual earnings (real value) & 29343.12 & 28710.43 & 27859.51 \\
\hline & Log hourly wage* & 2.632 & 2.652 & 2.672 \\
\hline & $\mathrm{N}$ & 291975 & 291975 & 291975 \\
\hline \multirow[t]{5}{*}{ Upper Secondary } & Employed t-1 period firm & .9229 & .8204 & .7205 \\
\hline & Employed & .9671 & .9376 & .9097 \\
\hline & Annual earnings (real value) & 30579.32 & 30432.83 & 30095.53 \\
\hline & Log hourly wage* & 2.674 & 2.696 & 2.718 \\
\hline & $\mathrm{N}$ & 749592 & 749592 & 749592 \\
\hline \multirow[t]{5}{*}{ Tertiary } & Employed t-1 period firm & .9137 & .8073 & .7092 \\
\hline & Employed & .9765 & .9273 & .9396 \\
\hline & Annual earnings (real value) & 45648.3 & 46289.62 & 46642.63 \\
\hline & Log hourly wage* & 2.929 & 2.959 & 2.989 \\
\hline & $\mathrm{N}$ & 469634 & 469634 & 469634 \\
\hline \multirow[t]{3}{*}{ Clerk } & Employed t-1 period firm & .9194 & .8120 & .7120 \\
\hline & Employed & .9680 & .9412 & .9195 \\
\hline & $\mathrm{N}$ & 58922 & 58922 & 58922 \\
\hline \multirow[t]{3}{*}{ Service } & Employed t-1 period firm & .9151 & .8067 & .7034 \\
\hline & Employed & .9621 & .9267 & .8933 \\
\hline & $\mathrm{N}$ & 132671 & 132671 & 132671 \\
\hline \multirow{3}{*}{$\begin{array}{l}\text { Operators and } \\
\text { assemblers }\end{array}$} & Employed t-1 period firm & .9284 & .8277 & .7274 \\
\hline & Employed & .9642 & .9299 & .8979 \\
\hline & $\mathrm{N}$ & 474553 & 474553 & 474553 \\
\hline Trades and & Employed t-1 period firm & .9203 & .8163 & .7117 \\
\hline \multirow[t]{2}{*}{ Construction workers } & Employed & .9654 & .9336 & .9014 \\
\hline & $\mathrm{N}$ & 334547 & 334547 & 334547 \\
\hline \multirow[t]{3}{*}{ Professional } & Employed t-1 period firm & .9169 & .8117 & .7124 \\
\hline & Employed & .9776 & .9574 & .9377 \\
\hline & $\mathrm{N}$ & 438755 & 438755 & 438755 \\
\hline \multirow[t]{3}{*}{ Managerial } & Employed t-1 period firm & .9075 & .7968 & .7021 \\
\hline & Employed & .9788 & .9574 & .9364 \\
\hline & $\mathrm{N}$ & 61481 & 61481 & 61481 \\
\hline$N$ & & $1,511,201$ & $1,511,201$ & $1,511,201$ \\
\hline
\end{tabular}


Table A2. Cont.

\begin{tabular}{|c|c|c|c|c|c|}
\hline Trade Measures & Period $t$ & Mean & St. Dev. & Min & Max \\
\hline & COFF $_{\mathrm{ijt}}$ (China Import/sales)\% & .4549 & 1.6895 & 0 & 252.3322 \\
\hline & $\mathrm{OFF}_{\mathrm{ijt}}$ (Total Import/sales)\% & 8.3414 & 26.9902 & 0 & 409.3564 \\
\hline & $\mathrm{CIP}_{\mathrm{ijt}}($ firm-specific)\% & 1.2526 & 3.5796 & 0 & 42.42448 \\
\hline & $\mathrm{IP}_{\mathrm{ijt}}($ firm-specific)\% & 19.9139 & 19.1516 & 0.8228 & 97.4334 \\
\hline & LI-OFF ${ }_{\mathrm{ijt}}$ (Low-income Import/sales)\% & 1.3070 & 3.5990 & 0 & 252.3322 \\
\hline & $\begin{array}{l}\text { LI-OFF-OTHER }{ }_{\mathrm{ijt}} \text { (Low-income Import } \\
\text { excl. China/sales)\% }\end{array}$ & 0.8521 & 3.0326 & 0 & 118.8611 \\
\hline & LI-IP ${ }_{\mathrm{ijt}}$ (Low-income, firm-specific)\% & 2.9716 & 5.6234 & 0.0005 & 52.4614 \\
\hline & $\begin{array}{l}\text { LI-IP-OTHER } \mathrm{ijt}_{\mathrm{t}} \text { (Low-income excl. } \\
\text { China, firm-specific)\% }\end{array}$ & 1.7190 & 3.0485 & 0 & 30.2759 \\
\hline \multicolumn{6}{|l|}{ Instruments } \\
\hline & CRES_INP ${ }_{\mathrm{jt}}$ & .0470 & .0652 & 0.00005 & .4856 \\
\hline & CRES_IND & .0476 & .0662 & 0.00005 & .4856 \\
\hline \multicolumn{6}{|c|}{ Background Characteristics } \\
\hline & Female & .2922 & .4548 & 0 & 1 \\
\hline & Number of children under 7 & .3159 & .6612 & 0 & 8 \\
\hline & Number of children under 18 & 0.8511 & 1.1131 & 0 & 14 \\
\hline & Age & 40.2623 & 9.1053 & 20 & 55 \\
\hline & Export share & .4140 & 0.5169 & 0 & 18.9224 \\
\hline & log firm size (number of employees) & 6.2519 & 1.9492 & 0 & 10.1252 \\
\hline & Tenure & 4.600 & 3.0528 & 1 & 10 \\
\hline & Primary & .1932 & 0.3948 & 0 & 1 \\
\hline & Secondary & .4960 & 0.5000 & 0 & 1 \\
\hline & Tertiary & .3108 & 0.4628 & 0 & 1 \\
\hline & Clerk & .0390 & 0.1936 & 0 & 1 \\
\hline & Service & .0878 & 0.2830 & 0 & 1 \\
\hline & Trades and Construction & .2214 & 0.4152 & 0 & 1 \\
\hline & Operators and Assemblers & .3140 & 0.4641 & 0 & 1 \\
\hline & Professional & .2903 & 0.4539 & 0 & 1 \\
\hline & Managerial & .0407 & 0.1978 & 0 & 1 \\
\hline$N$ & & $1,511,201$ & & & \\
\hline
\end{tabular}




\section{Appendix B}

Table B1. First stage results for regressions for annual labor income and hourly wage IV regressions.

\begin{tabular}{|c|c|c|c|c|c|c|}
\hline & $(1)$ & $(2)$ & 3) & (4) & (5) & $(6)$ \\
\hline Specification & \multicolumn{3}{|c|}{ Annual labor income } & \multicolumn{3}{|c|}{ Log hourly wage } \\
\hline PANEL A & $\mathrm{COFF}_{\mathrm{ijt}}$ & & & & & \\
\hline CRES_INP $_{\text {it }}$ & $\begin{array}{l}14.8173^{* * *} \\
(3.3526)\end{array}$ & & & & & \\
\hline PANEL B & $\mathrm{CIP}_{\mathrm{ijt}}$ & & & & & \\
\hline CRES_IND $_{\mathrm{jt}}$ & $\begin{array}{l}13.8353 * * \\
(5.5629\end{array}$ & & & & & \\
\hline PANEL C & $\mathrm{COFF}_{\mathrm{ijt}}$ & $\mathrm{COFF}_{\mathrm{ijt}}{ }^{*}$ tertiary & & $\mathrm{COFF}_{\mathrm{ijt}}$ & $\mathrm{COFF}_{\mathrm{ijt}}{ }^{*}$ tertiary & \\
\hline CRES_INP $_{\mathrm{jt}}$ & $\begin{array}{l}11.3914 * * * \\
(2.6843)\end{array}$ & $\begin{array}{l}-0.5162 \\
(0.6861)\end{array}$ & & $\begin{array}{l}11.9518^{* * * *} \\
(2.9963)\end{array}$ & $\begin{array}{l}-0.8868 \\
(0.9071)\end{array}$ & \\
\hline CRES_INP $_{\mathrm{it}}$ *tertiary & $\begin{array}{l}6.8502^{* * *} \\
(1.2488)\end{array}$ & $\begin{array}{l}19.0401^{* * *} \\
(3.6784)\end{array}$ & & $\begin{array}{l}7.1078^{* * *} \\
(1.1222)\end{array}$ & $\begin{array}{l}20.5800^{* * *} \\
(3.1535)\end{array}$ & \\
\hline PANEL D & $\mathrm{CIP}_{\mathrm{ijt}}$ & $\mathrm{CIP}_{\mathrm{ijt}}$ *tertiary & & $\mathrm{CIP}_{\mathrm{ijt}}$ & $\mathrm{CIP}_{\mathrm{ijt}}$ *tertiary & \\
\hline CRES_IND ${ }_{\mathrm{jt}}$ & $\begin{array}{l}18.4786 * * * \\
(5.0486)\end{array}$ & $\begin{array}{l}-1.4198 * * * \\
(0.3222)\end{array}$ & & $\begin{array}{l}14.0617 * * * \\
(5.0420)\end{array}$ & $\begin{array}{l}-1.2654 * * * \\
(0.3621)\end{array}$ & \\
\hline CRES_IND ${ }_{\mathrm{jt}}$ *tertiary & $\begin{array}{l}-9.4169 * * * \\
(1.8335)\end{array}$ & $\begin{array}{l}10.4027 * * \\
(4.6551)\end{array}$ & & $\begin{array}{l}-8.7899 * * * \\
(2.6340)\end{array}$ & $\begin{array}{l}6.1317^{* *} \\
(2.5148)\end{array}$ & \\
\hline Observations & $1,511,3201$ & $1,511,368$ & & $1,024,069$ & $1,024,069$ & \\
\hline PANEL E & $\mathrm{COFF}_{\mathrm{ijt}}$ & $\mathrm{COFF}_{\mathrm{ijt}}$ *tertiary & $\begin{array}{l}\mathrm{COFF}_{\mathrm{ijt}} \\
\text { *production }\end{array}$ & $\mathrm{COFF}_{\mathrm{ijt}}$ & $\mathrm{COFF}_{\mathrm{ijt}}{ }^{*}$ tertiary & $\begin{array}{l}\mathrm{COFF}_{\mathrm{ijt}} \\
\text { *production }\end{array}$ \\
\hline CRES_INP $_{\mathrm{jt}}$ & $\begin{array}{l}13.8446 * * * \\
(2.9675)\end{array}$ & $\begin{array}{l}0.1098 \\
(0.7346)\end{array}$ & $\begin{array}{l}-0.9600 * \\
(0.5296)\end{array}$ & $\begin{array}{l}14.9589 * * * \\
(2.9231)\end{array}$ & $\begin{array}{l}-0.2376 \\
(1.0670)\end{array}$ & $\begin{array}{l}-1.3924 * * * \\
(0.5332)\end{array}$ \\
\hline CRES_INP ${ }_{\mathrm{jt}} *$ tertiary & $\begin{array}{l}-4.6348 * * * \\
(1.3162)\end{array}$ & $\begin{array}{l}18.4700^{* * *} \\
(3.6988)\end{array}$ & $\begin{array}{l}0.7358^{*} \\
(0.4049)\end{array}$ & $\begin{array}{l}4.3987^{* * *} \\
(1.2999)\end{array}$ & $\begin{array}{l}19.9965 * * * \\
(3.2985)\end{array}$ & $\begin{array}{l}0.9752^{* *} \\
(0.4713)\end{array}$ \\
\hline CRES_INP $_{\mathrm{jt}}{ }^{*}$ production & $\begin{array}{l}-3.8179 * * * \\
(1.0130)\end{array}$ & $\begin{array}{l}-0.9669 * * * \\
(0.1926)\end{array}$ & $\begin{array}{l}10.3479 * * * \\
(1.7721)\end{array}$ & $\begin{array}{l}-4.8619 * * * \\
(0.8455)\end{array}$ & $\begin{array}{l}-1.0476^{* * * *} \\
(0.2008)\end{array}$ & $\begin{array}{l}11.4866^{* * *} \\
(2.1859)\end{array}$ \\
\hline PANEL F & $\mathrm{CIP}_{\mathrm{ijt}}$ & $\mathrm{CIP}_{\mathrm{ijt}}$ *tertiary & $\begin{array}{l}\mathrm{CIP}_{\text {ijt }} \\
\text { *production }\end{array}$ & $\mathrm{CIP}_{\mathrm{ijt}}$ & $\mathrm{CIP}_{\mathrm{ijt}}$ *tertiary & $\begin{array}{l}\mathrm{CIP}_{\mathrm{ijt}} \\
\text { *production }\end{array}$ \\
\hline CRES_IND $_{\mathrm{jt}}$ & $\begin{array}{l}16.4128 * * * \\
(5.2197)\end{array}$ & $\begin{array}{l}-2.0495 * * * \\
(0.3107)\end{array}$ & $\begin{array}{l}-4.2404 \\
(3.7356)\end{array}$ & $\begin{array}{l}12.0506 * * \\
(4.8281)\end{array}$ & $\begin{array}{l}-1.6601 * * * \\
(0.2553)\end{array}$ & $\begin{array}{l}-1.1967 \\
(3.0589)\end{array}$ \\
\hline CRES_IND ${ }_{\mathrm{jt}}{ }^{*}$ tertiary & $\begin{array}{l}-7.4887 * * * \\
(1.4547)\end{array}$ & $\begin{array}{l}11.0193^{* *} \\
(4.9177)\end{array}$ & $\begin{array}{l}3.8495 \\
(3.0304)\end{array}$ & $\begin{array}{l}-6.9556 * * * \\
(2.3106)\end{array}$ & $\begin{array}{l}6.4936^{* *} \\
(2.8212)\end{array}$ & $\begin{array}{l}1.0762 \\
(2.5847)\end{array}$ \\
\hline CRES_IND $_{\mathrm{jt}}$ *production & $\begin{array}{l}3.1812^{* *} \\
(1.5422)\end{array}$ & $\begin{array}{l}0.9457 * * \\
(0.4325)\end{array}$ & $\begin{array}{l}28.9163^{* * *} \\
(6.9289)\end{array}$ & $\begin{array}{l}3.2195^{* *} \\
(1.3655)\end{array}$ & $\begin{array}{l}0.6344 \\
(0.5052)\end{array}$ & $\begin{array}{l}19.8701^{* * *} \\
(6.7349)\end{array}$ \\
\hline Observations & $1,506,766$ & $1,506,766$ & $1,506,766$ & $1,024,069$ & $1,024,069$ & $1,024,069$ \\
\hline
\end{tabular}


Table B2. The effect of offshoring and import competition from low-income countries on employment (FE).

\begin{tabular}{|c|c|c|c|c|c|c|}
\hline & $(1)$ & $(2)$ & (3) & (4) & $(5)$ & $(6)$ \\
\hline & \multicolumn{3}{|c|}{ Same firm employment } & \multicolumn{3}{|c|}{ Employment } \\
\hline Time Period & $\mathrm{t}$ & $t+1$ & $t+2$ & $\mathrm{t}$ & $t+1$ & $t+2$ \\
\hline \multicolumn{7}{|l|}{ PANEL A } \\
\hline $\mathrm{LI}^{-O F F_{i j t}}$ & $\begin{array}{l}0.00009 \\
(0.002)\end{array}$ & $\begin{array}{l}-0.0035 \\
(0.004)\end{array}$ & $\begin{array}{l}-0.0041 \\
(0.004)\end{array}$ & $\begin{array}{l}0.0008 \\
(0.001)\end{array}$ & $\begin{array}{l}-0.0012 \\
(0.001)\end{array}$ & $\begin{array}{l}-0.0015^{*} \\
(0.001)\end{array}$ \\
\hline R-squared & 0.103 & 0.173 & 0.221 & 0.041 & 0.037 & 0.051 \\
\hline \multicolumn{7}{|l|}{ PANEL B } \\
\hline $\mathrm{COFF}_{\mathrm{ijt}}$ & $\begin{array}{l}-0.0060 \\
(0.005)\end{array}$ & $\begin{array}{l}-0.0147 \\
(0.009)\end{array}$ & $\begin{array}{l}-0.0109 * \\
(0.006)\end{array}$ & $\begin{array}{l}0.0010 \\
(0.001)\end{array}$ & $\begin{array}{l}-0.0020 \\
(0.002)\end{array}$ & $\begin{array}{l}-0.0013 \\
(0.001)\end{array}$ \\
\hline LI-OFF-OTHER & $\begin{array}{l}0.0044 * \\
(0.002)\end{array}$ & $\begin{array}{l}0.0044 \\
(0.004)\end{array}$ & $\begin{array}{l}0.0007 \\
(0.004)\end{array}$ & $\begin{array}{l}0.0008 \\
(0.001)\end{array}$ & $\begin{array}{l}-0.0007 \\
(0.001)\end{array}$ & $\begin{array}{l}-0.0016 \\
(0.001)\end{array}$ \\
\hline R-squared & 0.104 & 0.175 & 0.221 & 0.041 & 0.037 & 0.051 \\
\hline \multicolumn{7}{|l|}{ PANEL C } \\
\hline LI-IP & $\begin{array}{l}-0.0035^{*} \\
(0.002)\end{array}$ & $\begin{array}{l}-0.0027 \\
(0.003)\end{array}$ & $\begin{array}{l}0.0001 \\
(0.003)\end{array}$ & $\begin{array}{l}-0.0016^{* *} \\
(0.001)\end{array}$ & $\begin{array}{l}-0.0012 * \\
(0.001)\end{array}$ & $\begin{array}{l}-0.0003 \\
(0.001)\end{array}$ \\
\hline R-squared & 0.103 & 0.173 & 0.220 & 0.041 & 0.037 & 0.051 \\
\hline \multicolumn{7}{|l|}{ PANEL D } \\
\hline $\mathrm{CIP}_{\mathrm{ijt}}$ & $\begin{array}{l}-0.0082^{* *} \\
(0.003)\end{array}$ & $\begin{array}{l}-0.0073^{*} \\
(0.004)\end{array}$ & $\begin{array}{l}-0.0042 \\
(0.004)\end{array}$ & $\begin{array}{l}-0.0029 * * * \\
(0.001)\end{array}$ & $\begin{array}{l}-0.0023^{* *} \\
(0.001)\end{array}$ & $\begin{array}{l}-0.0016 \\
(0.001)\end{array}$ \\
\hline LI-IP-OTHER $_{\mathrm{ijt}}$ & $\begin{array}{l}0.0037 * * \\
(0.002)\end{array}$ & $\begin{array}{l}0.0044 \\
(0.003)\end{array}$ & $\begin{array}{l}0.0069 * * \\
(0.003)\end{array}$ & $\begin{array}{l}0.0005 \\
(0.001)\end{array}$ & $\begin{array}{l}0.0006 \\
(0.001)\end{array}$ & $\begin{array}{l}0.0016 * \\
(0.001)\end{array}$ \\
\hline R-squared & 0.104 & 0.174 & 0.221 & 0.041 & 0.037 & 0.051 \\
\hline Obs. & $1,511,201$ & $1,511,201$ & $1,511,201$ & $1,511,201$ & $1,511,201$ & $1,511,201$ \\
\hline
\end{tabular}

Table B3. The effect of offshoring and import competition on employment and earnings- OLS and firm- FE.

\begin{tabular}{|c|c|c|c|c|c|c|}
\hline \multirow[b]{3}{*}{ Panel A } & (1) & (2) & (3) & (4) & (5) & (6) \\
\hline & \multicolumn{3}{|c|}{ Same firm employment at $\mathrm{t}$} & \multicolumn{3}{|c|}{ Employment at t } \\
\hline & OLS & firm FE & $\begin{array}{l}\text { individual- } \\
\text { firm FE }\end{array}$ & OLS & firm FE & $\begin{array}{l}\text { individual-firm } \\
\text { FE }\end{array}$ \\
\hline $\mathrm{COFF}_{\mathrm{ijt}}$ & $\begin{array}{l}-0.0077^{*} \\
(0.0040)\end{array}$ & $\begin{array}{l}-0.0086 \\
(0.0076)\end{array}$ & $\begin{array}{l}-0.0063 \\
(0.0049)\end{array}$ & $\begin{array}{l}-0.0018 * * * \\
(0.0006)\end{array}$ & $\begin{array}{l}0.0001 \\
(0.0009)\end{array}$ & $\begin{array}{l}0.0009 \\
(0.0012)\end{array}$ \\
\hline Observations & $1,511,201$ & $1,511,201$ & $1,511,201$ & $1,511,201$ & $1,511,201$ & $1,511,201$ \\
\hline R-squared & 0.0318 & 0.0811 & 0.1031 & 0.0155 & 0.0383 & 0.0408 \\
\hline \multirow[t]{2}{*}{ Panel B } & \multicolumn{3}{|c|}{ Same firm employment at t } & \multicolumn{3}{|c|}{ Employment at t } \\
\hline & OLS & firm FE & $\begin{array}{l}\text { individual- } \\
\text { firm FE }\end{array}$ & OLS & firm FE & $\begin{array}{l}\text { individual-firm } \\
\text { FE }\end{array}$ \\
\hline $\mathrm{CIP}_{\mathrm{ijt}}$ & $\begin{array}{l}-0.0027 * * \\
(0.0012)\end{array}$ & $\begin{array}{l}-0.0118 * * \\
(0.0056)\end{array}$ & $\begin{array}{l}-0.0113^{* *} \\
(0.0051)\end{array}$ & $\begin{array}{l}-0.0009 * * * \\
(0.0002)\end{array}$ & $\begin{array}{l}-0.0020 * * * \\
(0.0007)\end{array}$ & $\begin{array}{l}-0.0022^{* *} \\
(0.0010)\end{array}$ \\
\hline Observations & $1,511,201$ & $1,511,201$ & $1,511,201$ & $1,511,201$ & $1,511,201$ & $1,511,201$ \\
\hline R-squared & 0.0309 & 0.0831 & 0.1057 & 0.0156 & 0.0385 & 0.0411 \\
\hline
\end{tabular}

